\title{
Original paper \\ Ordovician metagranites and migmatites of the Svratka and Orlice-Sněžník units, northeastern Bohemian Massif
}

\author{
David BURIÁNEK ${ }^{1,2^{*}}$, Kryštof VERNER ${ }^{3,4}$, Pavel HANŽL' ${ }^{1}$, Hana KRUMLOVÁ ${ }^{1}$ \\ ${ }^{1}$ Czech Geological Survey, Leitnerova 22, 65859 Brno, Czech Republic; david.burianek@geology.cz \\ ${ }^{2}$ Department of Geology, Faculty of Science, Masaryk University, Kotlářská 2, 61137 Brno, Czech Republic \\ ${ }^{3}$ Czech Geological Survey, Klárov 3, 11821 Prague 1, Czech Republic \\ ${ }^{4}$ Institute of Petrology and Structural Geology, Faculty of Science, Charles University, Albertov 6, 12843 Prague 2, Czech Republic \\ * Corresponding author
}

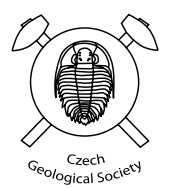

\begin{abstract}
Metagranites and migmatites of the Svratka and the Orlice-Sněžník units, northeastern Bohemian Massif, exhibit a number of similarities in their lithological, mineralogical and geochemical features. Both of these units were affected by intense migmatitization accompanied by intrusion of peraluminous granites during the Cambrian to Ordovician. The chemical composition and mineralogy of all the studied rocks correspond to crustal melts. From the geochemical point of view, both rock groups (migmatites and metagranites) exhibit progressive geochemical fractionation (increase in the $\mathrm{SiO}_{2}, \mathrm{Rb}, \mathrm{X}_{\mathrm{FeO}}$, W and Sn contents, accompanied by a decrease in the concentrations of $\mathrm{Ba}, \mathrm{Sr}, \mathrm{Mg}$ and $\mathrm{Ca}$ ) as a result of varying degrees of partial melting and fractional crystallization. The main rock-forming minerals are influenced by metamorphic recrystallization under amphibolite-facies conditions during the Variscan orogeny.
\end{abstract}

Keywords: Bohemian Massif, Cambro-Ordovician rifting, geochemistry, metagranite, migmatite, microstructures, Variscan orogeny Received: 11 March 2009; accepted 19 June 2009; handling editor: J. Žák

The online version of this article (http://dx.doi.org/10.3190/jgeosci.049) contains supplementary electronic material.

\section{Introduction}

The Svratka Unit (SU) and the Orlice-Sněžník Unit (OSU) are two rock assemblages exposed in the NE segment of the Bohemian Massif (Central European Variscides). In a broad sense, the studied area represents a collage of Gondwana-derived crustal segments affected by Late Devonian-Early Carboniferous Variscan tectonometamorphic activity (e.g., Winchester et al. 2002). The main rock types of these units originated in an evolved continental crust, the mean crustal residence ages of which range from Precambrian to Early Palaeozoic (for a review see Hegner and Kröner 2000). Both units exhibit a large number of analogies in their lithological composition, as well as in the timing of their protolith formation and the subsequent regional tectonometamorphic processes (e.g., Kröner et al. 2001; Schulmann et al. 2005). The SU and the OSU are composed of metagranites, orthogneisses, deformed migmatites, migmatized gneisses, micaschists, and paragneisses with thin intercalations of high-pressure rocks (eclogites and skarns). In terms of regional subdivision of the Bohemian Massif, the studied units belong to two distinct crustal domains: (i) the OSU is a part of the Lugian Unit (Upper Proterozoic to Lower Palaeozoic metagranite and meta-volcanosedimentary sequence with $\sim \mathrm{MP}-\mathrm{MT}$ Variscan overprint (Cymerman et al. 1997; Štípská et al. 2001) and (ii) the SU represents the exhumed lower- to mid-crustal level of the continental crust affected by HP-HT and LP-HT metamorphic overprint, otherwise Variscan orogenic root (for a review, see e.g. Urban and Synek 1995; Verner et al. in this volume).

This paper presents new integrated petrological, geochemical and microstructural data from crystalline rocks of the Svratka and Orlice-Sněžník units in order to address the following issues: (i) full-range petrological, geochemical and mineralogical subdivision of the main rock types of the SU and the OSU; (ii) genesis, especially in relation to pre-Variscan geodynamic processes (Cadomian orogeny to Early Palaeozoic rifting), and correlation of their compositions with neighbouring units; and (iii) the extent and character of secondary changes in composition and textures aiming to assess the magnitude of the Variscan tectonometamorphic overprint. Our studies of the Cambro-Ordovician migmatites and metagranites in both units may provide an excellent link between the pre-Variscan high-grade metamorphism, related magmatic activity and, in addition, the definition of character and intensity Variscan deformations. These results are complementary to other papers in this volume (Verner et al. this volume). 


\section{Geological setting}

\subsection{The Svratka Unit (SU)}

The SU crops out in the NE part of the Bohemian Massif, between two contrasting lithotectonic units - the Moldanubian Zone in the SE (exhumed lower- to midcrustal Variscan crust; Urban and Synek 1995) and the Polička Unit in the NE (Buriánek et al. 2003) (Fig. 1). In general, the metamorphic fabrics in the SU are roughly parallel to the lithological boundaries of major rock types and regional structures in the host metamorphic units. The regional metamorphic foliations in the SU dip steeply to moderately to the NNE or SE and are associated with stretching lineation gently plunging to the SE and NW (for details see Verner et al. this volume). The $\mathrm{SU}$ is composed of deformed leucocratic migmatites and fine-grained metagranites with layers of two-mica paragneisses, micaschists and coarse-grained porphyritic metagranites. The rocks of the SU differ from those of the Moldanubian Zone by a lower degree of Variscan metamorphic overprint (Tajčmanová et al. 2006), the presence of two-mica schists and Lower Palaeozoic coarse-grained porphyritic metagranites. Furthermore, the radiometric dating (coarse-grained metagranites; conventional U-Pb method on zircons) revealed three different stages of development of these rocks (Schulmann et al. 2005): (i) $1932 \pm 7 \mathrm{Ma}$ - inherited (upper intercept) age indicating that the granite protolith was probably derived from the melting of Late Palaeoproterozoic basement, (ii) $515 \pm 9 \mathrm{Ma}$ - timing the granite crystallization and (iii) $\sim 340 \mathrm{Ma}$, reflecting the Variscan tectonometamorphic overprint (e.g. Lange et al. 2003, 2005). The regional metamorphic conditions of the SU were estimated at $\sim 640-670^{\circ} \mathrm{C}$ and 6-8 kbar (Tajčmanová et al. 2006; Buriánek and Čopjaková 2008). This metamorphic event was recorded especially in the micaschists by stable Ms $+\mathrm{Bt}+\mathrm{Grt}+\mathrm{St}$ and Ky mineral assemblage. The presence of new sillimanite aggregates is probably associated with a retrograde metamorphic event at $\sim 580-650{ }^{\circ} \mathrm{C}$ and 6 kbar (Buriánek and Čopjaková 2008). The relicts of HP pre-Variscan metamorphic assemblages inside skarn boudins were also established (estimated pressures about $\sim 14$ kbar; Pertoldová et al. this volume).

\subsection{The Orlice-Sněžník Unit (OSU)}

The OSU is situated in the eastern part of the Lugian Unit (NE margin of the Bohemian Massif) and is divided into two main rock series: Sněžník and Stronie groups (Opletal et al. 1980; Mísař et al. 1983).

The OSU is bound by the Variscan granitoid to the north and the Olešnice-Uhřinov Fault separates the OSU from the Nové Město phyllites in the west. At the eastern boundary, the rocks of the OSU are thrust over the Stare Město Crystalline Complex and the Silesian Domain (Štípská et al. 2001) and in the south they occur in the footwall of the Zábřeh Crystalline Complex (Svoboda 1966). The regional trend of steeply dipping metamorphic foliations is WNW-ESE to NNW-SSE.

The Sněžník Group contains various types of deformed metagranites and migmatites with tectonic bodies of mafic and acidic HP to UHP rocks (Kryza et al. 1996). The UHP episode was dated by Bröcker et al. (2009) at 387-360 Ma and these rocks were interpreted as a result of a ductile extrusion from the lower crust (Štípská et al. 2004), or as having been tectonically inserted into the surrounding migmatites along localized subvertical shear zones (e.g. Stawikowski 2002). The coarse-grained porphyritic metagranites are usually described as Sněžník gneisses (Don et al. 1990). The prevailing rocks in this sub-unit are stratified from medium-grained to finegrained migmatites, known in the Polish terminology as Gierałtów gneisses (Don et al. 1990). The anatexis producing these migmatites was dated by Żelaźniewicz et al. (2006) at $485 \pm 12 \mathrm{Ma}$. The emplacement of metagranites was probably related to a major Cambro-Ordovician magmatic event (dated at 502-515 Ma; Kröner et al. 2000). The Variscan age (342 $\pm 6 \mathrm{Ma}, \mathrm{U}-\mathrm{Pb}$ dating) of zircon overgrowths in the migmatites was interpreted as the result of HT metamorphism (Turniak et al. 2000). The zircon xenocrysts yielded a wide range of ages from 546 to $2070 \mathrm{Ma}$, pointing to a relatively heterogeneous source of the metagranite protolith.

The Stronie Group represents a variable sequence of biotite and two-mica gneisses and micaschists with intercalations of graphitic quartzites, quartzitic shales, dolomitic marbles, calc-silicate rocks and amphibolites. The rocks of the Stronie Group were metamorphosed under amphibolite-facies conditions $\left(\mathrm{T}=550-650^{\circ} \mathrm{C}\right.$ and $\mathrm{P}=5.5-6.5 \mathrm{kbar}$ ) at $346.5 \pm 4.4 \mathrm{Ma}$ (for review see Jastrzębski in print). A pre-Variscan HT tectonometamorphic event (E-W-trending ductile fabric in relics; Přikryl et al. 1996) has been distinguished in the metagranite and migmatite bodies of the OSU. In addition, rocks of the OSU underwent polyphase Variscan tectonometamorphic evolution (Přikryl et al. 1996; Cymerman et al. 1997). Fig. 1 Simplified geological maps of the Svratka and the Orlice-Sněžník units on the eastern margin of the Bohemian Massif. a - Sketch map of the Svratka Unit (modified from Melichar ed., 2008; Mrázová ed. 2008; Hanžl ed. 2008a, Hanžl ed. 2008; Buriánek ed. 2009; Stárková et al. 1996). Sample locations are also shown. b-Geological outline of the Orlice-Sněžník Unit (modified from Stárková et al. 1996; Gawlikowska and Opletal 1997; Stárková et al. 1998) with sample locations. 


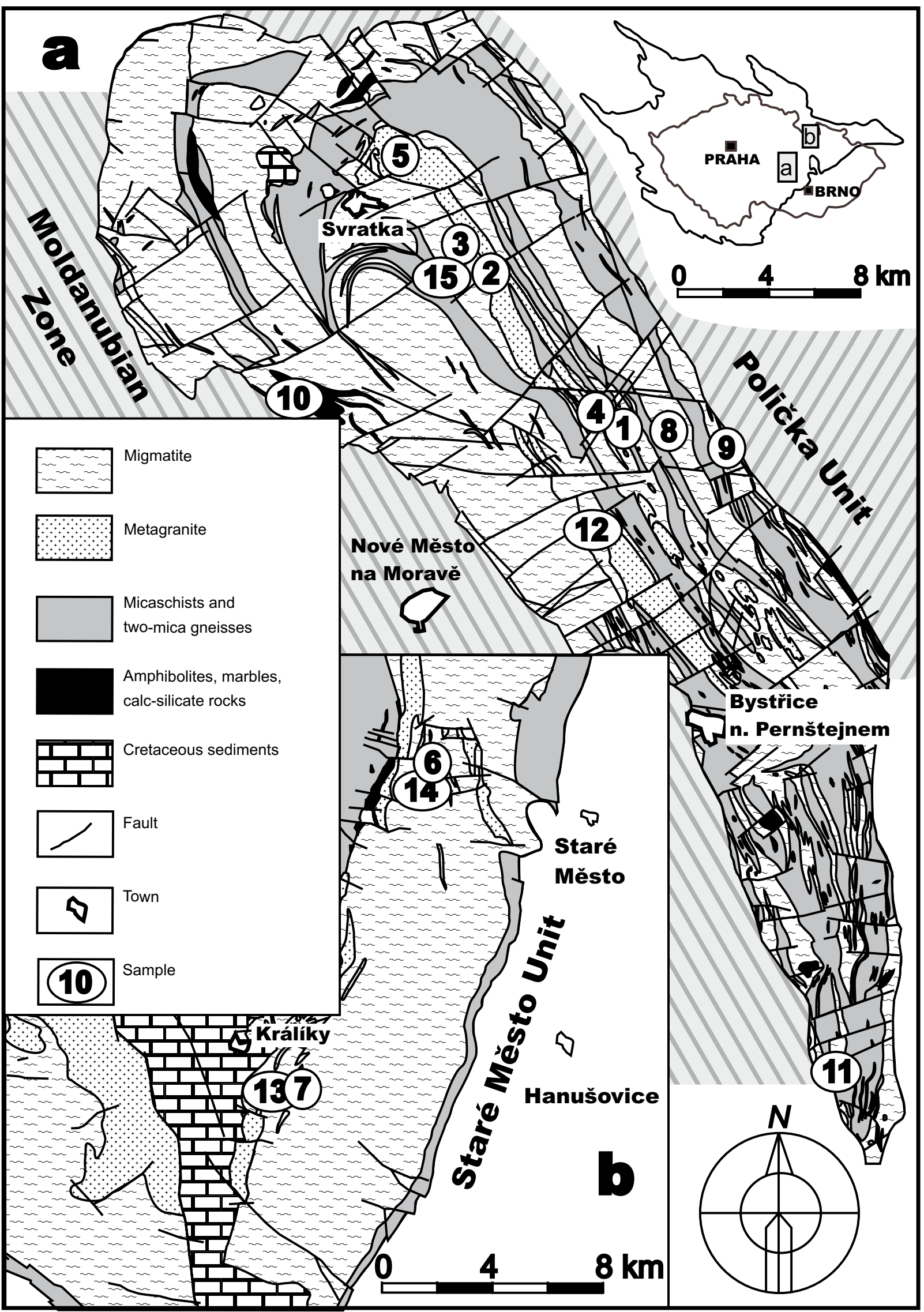




\section{Methodology}

We have selected 15 samples representing variations in the geochemical composition and mineralogical and textural characteristics.

Mineral analyses were obtained using the Cameca SX-100 electron microprobe at the Department of Geological Sciences, Faculty of Science, Masaryk University in Brno. The measurements were carried out in a wave dispersion mode under the following conditions: $15 \mathrm{kV}$ acceleration voltage, $5 \mu \mathrm{m}$ of the electron beam diameter, $30 \mathrm{nA}$ current, integration time 20 seconds. Solely $\mathrm{K}_{\alpha} \mathrm{X}$-ray lines were used as standards: augite $(\mathrm{Si}, \mathrm{Mg})$, orthoclase $(\mathrm{K})$, jadeite $(\mathrm{Na})$, chromite $(\mathrm{Cr})$, almandine $(\mathrm{Al})$, andradite $(\mathrm{Fe}, \mathrm{Ca})$, rhodonite $(\mathrm{Mn}), \mathrm{TiO}_{2}(\mathrm{Ti})$. The empirical formulae of feldspars were recalculated to 8 oxygen atoms and the crystallochemical formulae of micas to 22 oxygen atoms. The abbreviations of mineral names correspond to Kretz (1983).

Whole-rock major- and trace-element analyses were carried out at Acme Analytical Laboratories, Ltd., Vancouver, Canada. Major oxides were analysed by the ICP-MS method. Loss on ignition (LOI) was calculated by weight difference after ignition at $1000{ }^{\circ} \mathrm{C}$. The rare earth and trace elements were analyzed by INAA and ICP-MS following a $\mathrm{LiBO}_{2}$ fusion. The detection limits for analyses were between 0.01 and $0.1 \mathrm{wt}$. \% for major elements, and 0.1 and $8 \mathrm{ppm}$ for trace elements. All whole-rock geochemical data presented in this article are also summarized in Pertoldová et al. (2007). Other whole-rock chemical analyses were taken from Buriánek ed. (2009), Hanžl ed. (2008a) and Melichar ed. (2008). Whereas 19 samples of metagranites and 34 samples of migmatites from the $\mathrm{SU}$ were subjected to analyses, only 5 metagranites and 12 migmatites from the OSU were analyzed. Geochemical data were recalculated using the GCDkit software package (Janoušek et al. 2006).

Neodymium isotope analyses for petrogenetic modelling were performed at the Radiogenic Isotope Laboratory of the Czech Geological Survey on a Finnigan MAT 262 thermal ionization mass spectrometer in a dynamic mode using a double Re filament assembly, following the procedure of Míková and Denková (2007). The instrumental mass fractionation was corrected assuming ${ }^{146} \mathrm{Nd} /{ }^{144} \mathrm{Nd}=0.7219$. The La Jolla reference material yielded an average ${ }^{143} \mathrm{Nd} /{ }^{144} \mathrm{Nd}$ ratio of $0.511854(1 \sigma=$ $0.000007,16$ values). The decay constants applied to agecorrect the isotopic ratios were taken from Lugmair and Marti (1978). The $\varepsilon_{\mathrm{i}}^{N d}$ values were obtained using the Bulk Earth parameters of Jacobsen and Wasserburg (1980); the two-stage Depleted Mantle Nd model ages $\left(\mathrm{T}_{D M}^{N d}\right)$ were calculated after Liew and Hofmann (1988).

\section{Petrology}

\subsection{Metagranites of the Svratka Unit}

The studied coarse-grained muscovite-biotite metagranites (Fig. 2a) are relatively homogeneous in modal composition. Textural variability is caused by recrystallization and deformation during the Variscan tectonometamorphic processes. These rocks contain some relicts of perthitic K-feldspar phenocrysts $\left(\mathrm{Or}_{90-95} \mathrm{Ab}_{5-10}\right)$ with low contents of $\mathrm{BaO}(0.1-0.2 \mathrm{wt} . \%)$, and relatively high concentrations of $\mathrm{P}_{2} \mathrm{O}_{5}$ (up to $0.2 \mathrm{wt}$. \%). They sometimes enclose smaller grains of quartz, plagioclase $\left(\mathrm{An}_{8-12}\right)$ and biotite. The proportion of K-feldspars and plagioclases in the matrix is approximately equivalent. The plagioclase aggregates exhibit weak normal zoning $\left(\mathrm{An}_{1-17}\right)$. In most cases, primary magmatic feldspars are recrystallized into a mosaic of K-feldspar (up to $0.2 \mathrm{~mm}$ in size), with relatively smaller amounts of albitic plagioclase and quartz aggregates. The microstructures and recrystallization phenomena in these rocks are described in a separate section. The majority of the euhedral and subhedral plagioclase inclusions in the K-feldspar exhibit several- $\mu \mathrm{m}$ thick rims of albitic composition $\left(\mathrm{An}_{1-5}\right)$ and cores of oligoclase $\left(\mathrm{An}_{12-15}\right)$. Biotite usually forms small, thick flakes. In the less deformed domains, the lamellar biotites form 2-10 $\mathrm{mm}$ flat, lenticular aggregates. They are very often rimed by a newly formed muscovite at the boundary with feldspars. In the intensively deformed domains, micas are concentrated into long bands where muscovite aggregates prevail over biotites. The chemical composition of biotite (Fig. 3a-b) corresponds to annite $\left(\mathrm{Al}^{\mathrm{VV}}=2.52-2.82 \mathrm{apfu} ; \mathrm{X}_{\mathrm{Fe}}=0.63-0.80\right)$. The fluorine contents are relatively low $(0.33-0.66 \mathrm{apfu})$. Thin and lamellar muscovites $\left(\mathrm{X}_{\mathrm{Fe}}=0.42-0.60\right)$ have subhedral flakes oriented parallel to the metamorphic foliation or form small inclusions in the individual K-feldspar grains. Apatite, zircon, monazite and ilmenite $\left(\mathrm{Ilm}_{94-97} \mathrm{Pyf}_{6-3}\right)$ are present as common accessory minerals, usually enclosed in biotite. Small isometric grains of garnets and sillimanite needles are exceptional in these rocks. Typological evolution of zircons (Pupin 1980) is characteristic of aluminous leucogranites (S-type). This is confirmed by the calculated indexes IA $=314$ and IT $=341$ (Buriánek et al. 2006).

\subsection{Metagranites of the Orlice-Sněžník Unit}

Coarse-grained to very coarse-grained porphyritic granites are often recrystallized. The structure of the rock is usually lepidogranoblastic (Fig. 2b) or porphyroclastic (in the less deformed domains where metagranite partly retains its original magmatic character). Highly deformed 

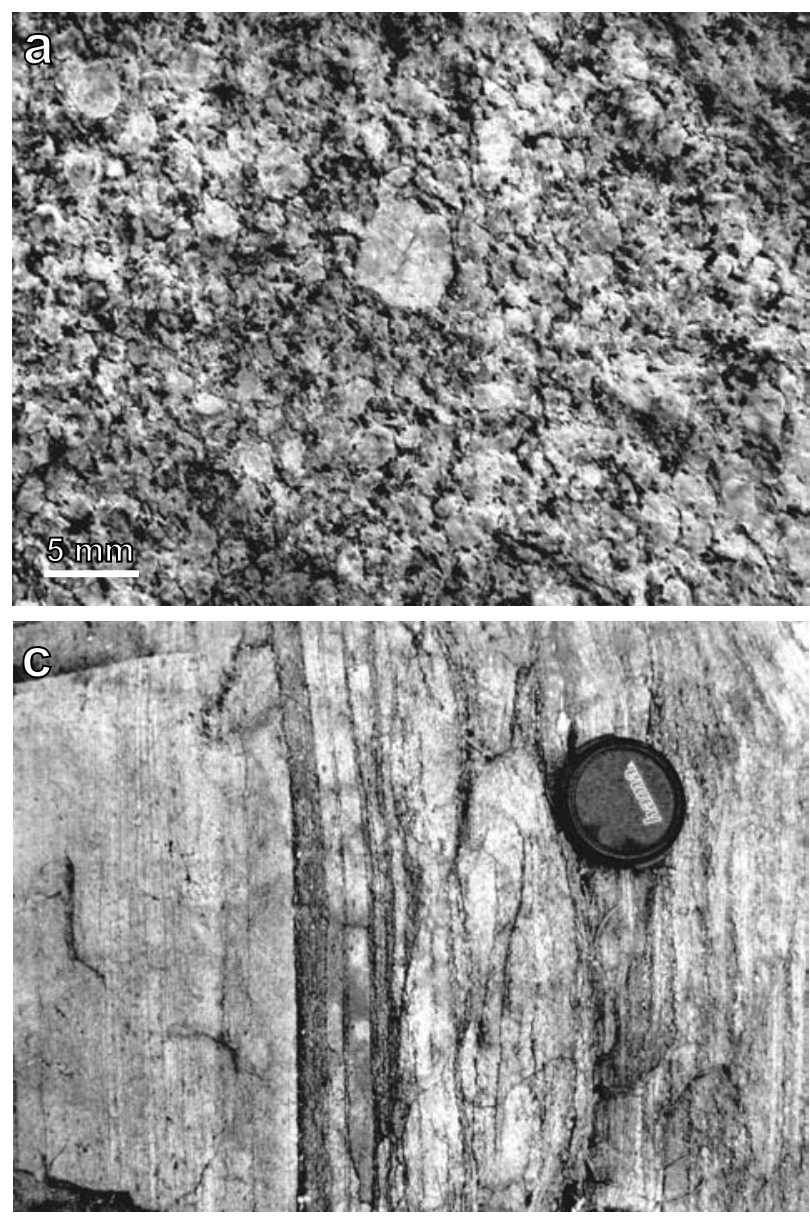
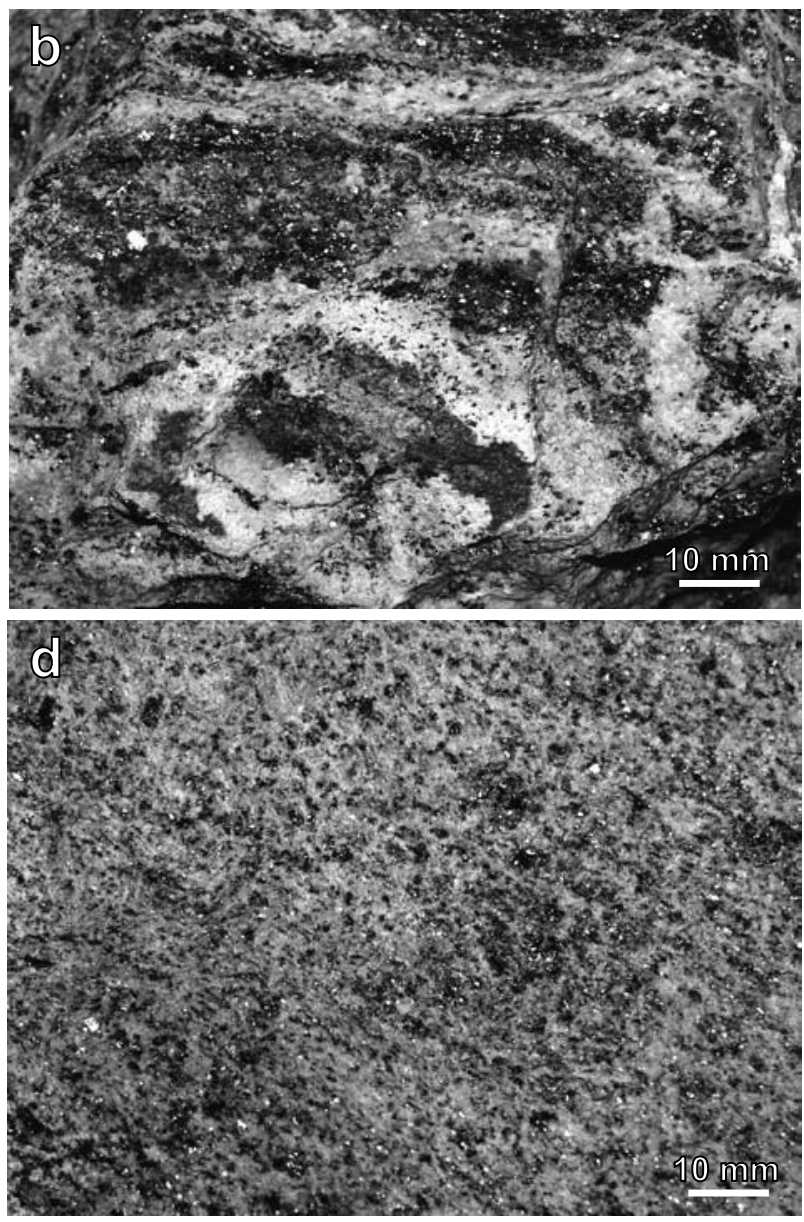

Fig. 2 Field photographs from the Svratka Unit (a, c) and Orlice-Sněžník Unit (b, d). a - Slightly deformed metagranite, Štarkov (sample No. 4); b - Intensively deformed metagranite (orthogneiss) from Jeřáb; c - Contact between metatexite and diatexite, Trhonice (sample No. 9); d - Diatexite to anatectic metagranite, Jeřáb (sample No. 13).

metagranites are banded or augen gneisses. In more deformed samples, quartz stripes alternate with bands composed of small grains of feldspars and flakes of micas. These rocks very rarely contain enclaves of finegrained biotitic orthogneisses. Anhedral quartz grains with undulatory extinction envelop small inclusions of biotite, apatite and zircon. K-feldspar porphyroclasts are slightly recrystallized to smaller grains along the edges. $\mathrm{K}$-feldspars $\left(\mathrm{Or}_{88-92} \mathrm{Ab}_{8-12}\right)$ are occasionally perthitic but they often exhibit myrmekitic intergrowths with plagioclase on the edges of the grains. The contents of $\mathrm{BaO}$ and $\mathrm{SrO}$ are $0.1-0.2$ wt. \% and $0.00-0.08$ wt. \%, respectively. The $\mathrm{P}_{2} \mathrm{O}_{5}$ concentrations are low and do not exceed $0.02 \mathrm{wt}$. \%. Larger phenocrysts sometimes envelop grains of plagioclase and biotite. Relicts of quartz phenocrysts and plagioclase are recrystallized into mosaic of small isometric grains. The observed normal zoning is mostly simple and seldom oscillatory $\left(\mathrm{An}_{13-24}\right)$. Biotite and muscovite form small flakes up to $1 \mathrm{~mm}$ in size. The modal abundance of biotite (2-8 vol. \%) is usually higher than that of muscovite (2-4 vol. \%). Biotite is often intergrown with muscovite and contains numerous inclusions of zircon and apatite. Some of the biotites are chloritized. In the heavily deformed domains, the micas are concentrated into long bands, in which biotite prevails over muscovite. Biotite (Fig. 3a-b) corresponds chemically to annite $\left(\mathrm{Al}^{\mathrm{IV}}=2.41-2.61\right.$ apfu; $\mathrm{X}_{\mathrm{Fe}}=0.71-0.80$; $\mathrm{F}=0.2-0.4 \mathrm{apfu})$ and is often accompanied by muscovite $\left(\mathrm{X}_{\mathrm{Fe}}=0.52-0.63\right)$. Accessory minerals are represented especially by apatite, zircon, monazite and ilmenite $\left(\mathrm{Ilm}_{95}\right.$ $\left.\mathrm{Pyf}_{5}\right)$. Small garnet grains occur infrequently $\left(\mathrm{Alm}_{73-74}\right.$ $\left.\mathrm{Grs}_{8-11} \operatorname{Sps}_{12-15} \operatorname{Prp}_{2-3} \mathrm{Adr}_{2}\right)$.

\subsection{Migmatites of the Svratka Unit}

Medium-grained leucocratic migmatites, often affected by regional sub-solidus deformation, are the main rock type of the SU. According to the structure, metatexite and 

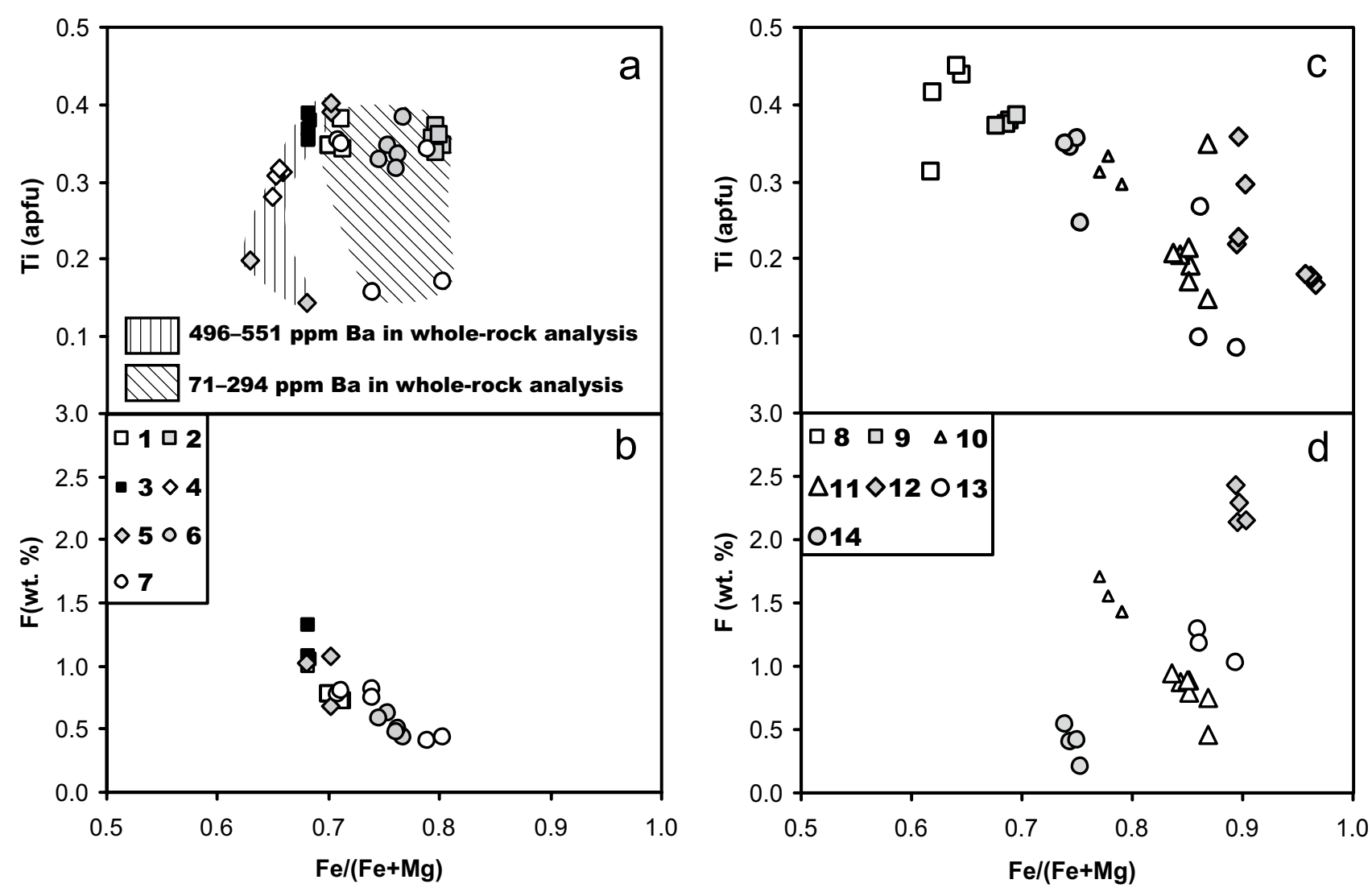

Fig. $3 \mathrm{Ti}$ vs. $\mathrm{Fe} /(\mathrm{Fe}+\mathrm{Mg})$ and $\mathrm{F}$ vs. $\mathrm{Fe} /(\mathrm{Fe}+\mathrm{Mg})$ diagrams for biotite (apfu) from metagranite (a-b) and migmatite (c-d); sample numbers as listed in Tab. 1.

Tab. 1 Localization of representative rock samples from the Svratka and the Orlice-Sněžník units

\begin{tabular}{ccclll}
\hline Sample No. & Longitude $\left({ }^{\circ} \mathbf{E}\right)$ & Latitude $\left({ }^{\circ} \mathbf{N}\right)$ & Rocks & Unit & Locality \\
\hline 1 & $16^{\circ} 10^{\prime} 44.95^{\prime \prime}$ & $49^{\circ} 38^{\prime} 05.04^{\prime \prime}$ & metagranite & SU & Rabuňka \\
2 & $16^{\circ} 06^{\prime} 55.09^{\prime \prime}$ & $49^{\circ} 40^{\prime} 06.86^{\prime \prime}$ & metagranite & SU & Vysoký kopec \\
3 & $16^{\circ} 10^{\prime} 10.94^{\prime \prime}$ & $49^{\circ} 35^{\prime} 41.08^{\prime \prime}$ & metagranite & SU & Vlčí kámen \\
4 & $16^{\circ} 10^{\prime} 19.91^{\prime \prime}$ & $49^{\circ} 38^{\prime} 22.24^{\prime \prime}$ & metagranite & SU & Štarkov \\
5 & $16^{\circ} 03^{\prime} 59.82^{\prime \prime}$ & $49^{\circ} 42^{\prime} 56.86^{\prime \prime}$ & metagranite & SU & Karlštejn \\
6 & $16^{\circ} 51^{\prime} 49.49^{\prime \prime}$ & $50^{\circ} 10^{\prime} 26.76^{\prime \prime}$ & metagranite & OSU & Sušina \\
7 & $16^{\circ} 48^{\prime} 56.08^{\prime \prime}$ & $50^{\circ} 03^{\prime} 19.39^{\prime \prime}$ & metagranite & OSU & Jeř́b \\
8 & $16^{\circ} 10^{\prime} 19.91^{\prime \prime}$ & $49^{\circ} 38^{\prime} 90.58^{\prime \prime}$ & diatexite & SU & Jimramov \\
9 & $16^{\circ} 14^{\prime} 50.25^{\prime \prime}$ & $49^{\circ} 37^{\prime} 47.03^{\prime \prime}$ & diatexite & SU & Trhonice \\
10 & $16^{\circ} 00^{\prime} 11.96^{\prime \prime}$ & $49^{\circ} 37^{\prime} 44.11^{\prime \prime}$ & metatexite & SU & Hudecká skalka \\
11 & $16^{\circ} 18^{\prime} 47.98^{\prime \prime}$ & $49^{\circ} 23^{\prime} 26.48^{\prime \prime}$ & metatexite & SU & Skryje \\
12 & $16^{\circ} 08^{\prime} 36.01^{\prime \prime}$ & $49^{\circ} 37^{\prime} 23.35^{\prime \prime}$ & diatexite & SU & Odranec \\
15 & $16^{\circ} 06^{\prime} 54.67^{\prime \prime}$ & $49^{\circ} 42^{\prime} 33.66^{\prime \prime}$ & diatexite & SU & Rybenské perničky \\
13 & $16^{\circ} 48^{\prime} 56.08^{\prime \prime}$ & $50^{\circ} 03^{\prime} 19.39^{\prime \prime}$ & diatexite & OSU & Jeřáb \\
14 & $16^{\circ} 49^{\prime} 21.16^{\prime \prime}$ & $50^{\circ} 01^{\prime} 11.39^{\prime \prime}$ & metatexite & OSU & U tř́i tabulí \\
\hline
\end{tabular}

of leucosome of $\mathrm{Pl}+\mathrm{Kfs}+\mathrm{Qtz} \pm$ $\mathrm{Bt} \pm \mathrm{Ms}$ composition. The melanosome layers $(\mathrm{mm}$ to $\mathrm{cm}$ in thickness) are highly enriched in biotite and muscovite aggregates. The chemical composition of biotite from aggregates corresponds to annite $\left(\mathrm{Al}^{\mathrm{IV}}=2.52-2.64 \mathrm{apfu}\right.$; $\left.\mathrm{X}_{\mathrm{Fe}}=0.77-0.87\right)(\mathrm{Fig} .3 \mathrm{c}-\mathrm{d})$, while muscovite $\left(\mathrm{X}_{\mathrm{Fe}} 0.65-0.72\right)$ locally occurs as tabular crystals up to several $\mathrm{mm}$ in length. The leucosome forms anhedral quartz grains, and contains small amounts of micas and subhedral to anhedral plagioclases $\left(\mathrm{An}_{2-10}\right)$ and $\mathrm{K}$-feldspars. The melanosome in metatexites can also contain diatexite were distinguished as two main migmatite types (Buriánek 2008). Diatexites gradually pass into metatexites on the outcrop scale. Metatexites (Fig. 2c) are more abundant in the south-eastern part of the SU.

The metatexites consist of medium- to fine-grained, banded rocks, containing small volumes ( $<30$ vol. \%) plagioclase with higher basicity $\left(\mathrm{An}_{12-16}\right)$. During anatexis, albite should be fractionated into the melt leaving a restite enriched in anorthite (Piwinski 1968). Some metatexites can also rarely contain garnet $\left(\mathrm{Alm}_{80-83} \mathrm{Grs}_{1-3}\right.$ $\left.\mathrm{Sps}_{10-14} \operatorname{Prp}_{2-3} \mathrm{Adr}_{2-3}\right)$. Garnet can by interpreted as relic mesosome according Kriegsman (2001). 
In the diatexites, felsic minerals prevail significantly over the mafic ones (the proportion of the dark components is usually bellow $5 \%$ ). The isolated mafic, biotiterich schlieren and enclaves with occasional garnet or tourmaline are sometimes present as several $\mathrm{dm}$ long stripes (Buriánek 2008). The diatexites were often found associated with leucocratic fine-grained metagranites with well-developed gradational contacts. The same diatexites and fine-grained metagranites can be classified as orthogneisses (Fig. 2d). Anhedral grains in the quartz aggregates exhibit undulose extinction. Subhedral plagioclases $\left(\mathrm{An}_{1-11}\right)$ predominate over anhedral K-feldspars. The plagioclases are oscillatory zoned; however, more frequently can be observed a thin zone of nearly pure albite $\left(\mathrm{An}_{2}\right)$ surrounding the central, somewhat more calcic domain $\left(\mathrm{An}_{6-10}\right)$. The individual zones vary mainly in the contents of $\mathrm{Ba}(0.00-0.03 \mathrm{apfu})$. K-feldspars $\left(\mathrm{Or}_{97-86} \mathrm{Ab}_{3-14}\right)$ contain up to $0.15 \mathrm{apfu} \mathrm{Ba}$. Some of the grains enclose quartz inclusions. Micas (3-12 vol. \%) are represented by biotite and muscovite in roughly equal proportions. Biotite encloses grains of apatite and zircon. The chemical composition of biotite (Fig. 3c-d) corresponds to annite $\left(\mathrm{Al}^{\mathrm{IV}}=2.38-2.66 \mathrm{apfu}, \mathrm{X}_{\mathrm{Fe}}=0.50-0.98\right)$. In some samples, a relatively high content of fluorine (1.1-1.2 apfu) was detected. Muscovite exhibits a rather broad range of $\mathrm{X}_{\mathrm{Fe}}(0.43-0.97)$, obviously depending on the degree of geochemical fractionation. Tourmaline is a relatively frequent accessory mineral in some types of migmatites. In the SU, tourmaline is concentrated especially in diatexites in the form of small veins or nodules (up to $2 \mathrm{~cm}$ in diameter). Subhedral tourmaline grains enclose small quartz and feldspar inclusions. Tourmaline corresponds to an aluminium-rich schorl $\left(\mathrm{X}_{\mathrm{Fe}}=0.93-0.96\right.$, $\mathrm{Al}=6.39-6.51 \mathrm{apfu}, \mathrm{Na}=0.67-0.83 \mathrm{apfu})$. The fluorine contents fluctuate between 0.2 and 0.3 apfu. Fluorapatite ( $\mathrm{F} \sim 0.8 \mathrm{apfu}$ ) is another common accessory mineral.

\subsection{Migmatites of the Orlice-Sněžník Unit}

The medium-grained two-mica leucocratic migmatites of the OSU are similar to the rocks of the SU. Migmatites mostly form elongated bodies of varying thickness (up to several hundred metres). The boundaries with the surrounding rocks (mainly two-mica gneisses and quartzitic gneisses) are usually well defined. Leucocratic migmatites are banded (metatexites) or homogeneous with only a mesoscopic fabric apparent (diatexites).

Metatexites contain foliation and/or banding, which survived partial melting. The leucosome layers with low content of biotite alternate with layers and spots with higher mica contents. The thickness of the bands can range from several millimetres to several centimetres. The leucosome layers consist mainly of anhedral quartz and subhedral feldspars. K-feldspars $\left(\mathrm{Or}_{90-91} \mathrm{Ab}_{9-10}\right)$ sometimes contain perthitic exsolutions and, together with plagioclases $\left(\mathrm{An}_{8-16}\right)$, are locally sericitized. The boundaries between plagioclase and $\mathrm{K}$-feldspar are sometimes decorated by myrmekites. Muscovite $\left(\mathrm{X}_{\mathrm{Fe}}\right.$ $=0.53-0.61)$ flakes are relatively equally distributed in the leucosome and melanosome. The chemical composition of biotite (Fig. $3 \mathrm{c}-\mathrm{d})$ corresponds to annite $\left(\mathrm{Al}^{\mathrm{IV}}=\right.$ $\left.2.48-2.57 \mathrm{apfu} ; \mathrm{X}_{\mathrm{Fe}}=0.74-0.75\right)$. The biotites are locally strongly chloritized.

Diatexite has been defined as a migmatite in which the pre-migmatization structures are destroyed and only isolated mafic schlieren and enclaves are present (Brown 1973). The medium-grained diatexites contain quartz, plagioclase, K-feldspar and minor biotite and muscovite. Quartz often exhibits distinct undulose extinction. K-feldspars $\left(\mathrm{Or}_{87-91} \mathrm{Ab}_{9-13}\right)$ are weakly replaced by clay minerals and sometimes contain perthitic exsolutions. Plagioclases $\left(\mathrm{An}_{6-12}\right)$ are locally sericitized. The boundaries between plagioclase and K-feldspar are sometimes decorated by myrmekites. Biotite (3-6 vol. \%) usually prevails over muscovite (2-5 vol. \%). The muscovite $\left(\mathrm{X}_{\mathrm{Fe}}=0.54-0.69\right)$ forms laths or is sometimes poikiloblastically intergrown with quartz. The biotite composition corresponds to annite $\left(\mathrm{Al}^{\mathrm{IV}}=2.39-2.49\right.$ apfu, $\left.\mathrm{X}_{\mathrm{Fe}}=0.86-0.89\right)$ (Fig. 3). Biotite contains inclusions of zircon, apatite, rutile, and small grains of ore minerals. Some of the biotites are strongly chloritized. Garnet $\left(\mathrm{Alm}_{65-82} \mathrm{Grs}_{3-12} \mathrm{Sps}_{10-22}\right.$ $\operatorname{Prp}_{1-3} \mathrm{Adr}_{1-3}$ ) forms small, round grains. Tourmaline was not found in the studied samples.

\subsection{Correlation of the whole-rock chemical composition and the biotite mineral chemistry}

Most of the studied metagranite samples from both the units of interest (the SU and the OSU) can be classified as only slightly fractionated melts. Metagranites, however, exhibit an obvious fractionation trend from the rocks with higher $\mathrm{Ba}$ and $\mathrm{Sr}$ contents to the rocks having smaller concentrations of these elements and higher contents of $\mathrm{Rb}$.

Geochemical evolution of the melt has also affected the composition of the biotites (Tab. 3). Biotite (Fig. 3a) from the less-fractionated rock samples (Ba 496-551 ppm) shows a lower value of $X_{\mathrm{Fe}}(0.64-0.68)$ than biotite $\left(\mathrm{X}_{\mathrm{Fe}}=0.75-0.80\right)$ from rocks that are more fractionated $(\mathrm{Ba}=71-294 \mathrm{ppm})$. On the other hand, the chemical composition of biotites within each of the samples tends to be rather homogeneous. Only the biotites located close to garnets or those forming pseudomorphs after this mineral exhibit low contents of Ti ( 0.20 apfu vs. usual 0.28-0.40 apfu). Increasing $\mathrm{X}_{\mathrm{Fe}}$ does not have a significant effect on the $\mathrm{Ti}$ concentration in biotites. However, a decrease in F and tetrahedral Al can be ob- 
Tab. 2 Selected geochemical, mineralogical and isotopic characteristics for studied samples (ordered according to Ba content in rocks)

\begin{tabular}{|c|c|c|c|c|c|c|c|c|}
\hline Sample No. & Rocks & Unit & $X_{F e}(B t)$ & F (Bt) wt \% & $\mathrm{X}_{\mathrm{FeO}}($ rock $)$ & $\mathbf{B a}$ & $\mathbf{R b}$ & $\mathrm{Sr}$ \\
\hline 12 & migmatite & SU & $0.90-0.96$ & $2.13-1.43$ & 0.92 & 22.0 & 567.3 & 15.9 \\
\hline 15 & migmatite & $\mathrm{SU}$ & n. d. & n. d. & 0.93 & 58.0 & 457.0 & 25.6 \\
\hline 1 & metagranite & SU & $0.70-0.71$ & n. d. & 0.89 & 71.0 & 440.3 & 17.9 \\
\hline 13 & migmatite & OSU & $0.86-0.89$ & $1.02-1.29$ & 0.89 & 118.8 & 293.7 & 23.2 \\
\hline 11 & migmatite & SU & $0.84-0.87$ & $0.46-0.94$ & 0.90 & 131.4 & 324.3 & 36.9 \\
\hline 8 & migmatite & $\mathrm{SU}$ & $0.62-0.65$ & n. d. & 0.78 & 151.2 & 126.8 & 177.3 \\
\hline 2 & metagranite & SU & $0.79-0.80$ & n. d. & 0.84 & 163.0 & 307.3 & 48.0 \\
\hline 6 & metagranite & OSU & $0.75-0.77$ & $0.43-0.63$ & 0.85 & 294.2 & 194.9 & 59.7 \\
\hline 14 & migmatite & OSU & $0.74-0.75$ & $0.21-0.54$ & 0.84 & 393.2 & 183.4 & 67.3 \\
\hline 3 & metagranite & OSU & 0.68 & $1.00-1.33$ & 0.77 & 495.6 & 205.8 & 126.4 \\
\hline 5 & metagranite & OSU & $0.63-0.70$ & $0.68-1.07$ & 0.78 & 500.0 & 257.1 & 112.3 \\
\hline 7 & metagranite & OSU & $0.71-0.80$ & $0.41-0.81$ & 0.82 & 512.3 & 199.5 & 90.7 \\
\hline 4 & metagranite & OSU & $0.64-0.66$ & $0.53-0.65$ & n. d. & 550.9 & 262.6 & 96.0 \\
\hline Sample No. & Rocks & Sm & Nd & ${ }^{147} \mathrm{Sm} /{ }^{144} \mathrm{Nd}$ & ${ }^{143} \mathrm{Nd} /{ }^{144} \mathrm{Nd}$ & $2 S(M) N d$ & $\varepsilon_{515}^{N d}$ & $\mathbf{T}_{\text {DM (Ga) }}$ \\
\hline 2 & metagranite & 4.2 & 16.4 & 0.1548 & 0.512232 & 0.000013 & -5.2 & 1.6 \\
\hline 4 & metagranite & 5.8 & 24.7 & 0.1419 & 0.512162 & 0.000011 & -5.7 & 1.6 \\
\hline 8 & migmatite & 6.2 & 26.0 & 0.1441 & 0.512122 & 0.000014 & -6.6 & 1.7 \\
\hline 15 & migmatite & 2.2 & 5.7 & 0.2333 & 0.512169 & 0.000013 & -11.6 & 2.1 \\
\hline
\end{tabular}

n. d. - not determined, $\mathrm{T}_{\mathrm{DM}}(\mathrm{Ga})$ - two-stage Depleted Mantle Nd model ages (Liew and Hofmann 1988)

$2 \mathrm{~S}(\mathrm{M})$ - standard error of the mean

Tab. 3 Chemical composition of biotite (wt. \% and apfu calculated on the basis of $22 \mathrm{O}$ )

\begin{tabular}{|c|c|c|c|c|c|c|c|c|c|c|c|c|}
\hline Sample No. & 3 & 6 & 10 & 10 & 11 & 11 & 12 & 15 & 15 & 15 & 14 & 14 \\
\hline $\mathrm{SiO}_{2}$ & 33.23 & 35.49 & 34.83 & 34.54 & 35.06 & 34.06 & 35.51 & 34.52 & 35.17 & 34.98 & 34.83 & 34.46 \\
\hline $\mathrm{TiO}_{2}$ & 3.09 & 2.97 & 2.85 & 2.50 & 1.63 & 1.44 & 0.44 & 1.93 & 0.81 & 2.26 & 2.94 & 2.08 \\
\hline $\mathrm{Al}_{2} \mathrm{O}_{3}$ & 18.16 & 17.66 & 18.77 & 18.51 & 21.13 & 19.53 & 19.49 & 19.61 & 19.03 & 18.49 & 17.36 & 18.34 \\
\hline $\mathrm{Cr}_{2} \mathrm{O}_{3}$ & 0.03 & 0.01 & 0.03 & 0.02 & 0.00 & 0.01 & 0.01 & 0.00 & 0.01 & 0.00 & 0.00 & 0.00 \\
\hline $\mathrm{FeO}$ & 24.07 & 25.31 & 25.65 & 25.97 & 24.79 & 27.81 & 26.83 & 28.73 & 26.98 & 28.01 & 24.67 & 25.36 \\
\hline $\mathrm{MnO}$ & 0.32 & 0.38 & 0.15 & 0.20 & 0.40 & 0.28 & 0.30 & 0.39 & 0.51 & 0.33 & 0.38 & 0.45 \\
\hline $\mathrm{MgO}$ & 6.32 & 4.67 & 4.10 & 3.87 & 2.41 & 2.74 & 4.20 & 1.88 & 2.46 & 2.53 & 4.87 & 4.66 \\
\hline $\mathrm{Na}_{2} \mathrm{O}$ & 0.06 & 0.09 & 0.11 & 0.06 & 0.08 & 0.16 & 0.15 & 0.14 & 0.06 & 0.03 & 0.07 & 0.06 \\
\hline $\mathrm{K}_{2} \mathrm{O}$ & 9.88 & 9.46 & 10.05 & 10.07 & 9.64 & 9.36 & 9.47 & 9.71 & 9.34 & 9.46 & 8.90 & 9.25 \\
\hline $\mathrm{F}$ & 1.08 & 0.63 & 1.56 & 1.43 & 0.89 & 0.89 & - & 2.13 & 1.29 & 1.19 & 0.54 & 0.21 \\
\hline $\mathrm{Cl}$ & - & 0.22 & - & - & 0.03 & 0.03 & - & - & 0.14 & 0.14 & 0.02 & 0.03 \\
\hline $\mathrm{H}_{2} \mathrm{O}^{*}$ & 3.29 & 3.50 & 3.12 & 3.13 & 3.41 & 3.35 & 3.89 & 2.81 & 3.11 & 3.21 & 3.52 & 3.68 \\
\hline $\mathrm{O}=\mathrm{F}, \mathrm{Cl}$ & 0.46 & 0.31 & 0.66 & 0.60 & 0.38 & 0.38 & 0.00 & 0.90 & 0.58 & 0.53 & 0.23 & 0.09 \\
\hline Total & 99.95 & 100.68 & 101.83 & 100.89 & 99.86 & 100.04 & 100.26 & 102.75 & 99.48 & 101.13 & 98.33 & 98.66 \\
\hline \multicolumn{13}{|l|}{ (apfu) } \\
\hline $\mathrm{Si}$ & 5.243 & 5.527 & 5.420 & 5.437 & 5.473 & 5.406 & 5.478 & 5.421 & 5.609 & 5.514 & 5.520 & 5.456 \\
\hline $\mathrm{Al}^{\mathrm{IV}}$ & 2.757 & 2.473 & 2.580 & 2.563 & 2.527 & 2.594 & 2.522 & 2.579 & 2.391 & 2.486 & 2.480 & 2.544 \\
\hline $\mathrm{Al}^{\mathrm{VI}}$ & 0.620 & 0.767 & 0.863 & 0.872 & 1.361 & 1.059 & 1.022 & 1.050 & 1.188 & 0.949 & 0.762 & 0.877 \\
\hline $\mathrm{Ti}$ & 0.366 & 0.348 & 0.333 & 0.296 & 0.191 & 0.172 & 0.051 & 0.228 & 0.097 & 0.268 & 0.350 & 0.247 \\
\hline $\mathrm{Cr}$ & 0.004 & 0.001 & 0.004 & 0.003 & 0.000 & 0.001 & 0.002 & 0.000 & 0.001 & 0.000 & 0.000 & 0.000 \\
\hline $\mathrm{Fe}$ & 3.177 & 3.297 & 3.338 & 3.420 & 3.237 & 3.692 & 3.461 & 3.773 & 3.600 & 3.692 & 3.269 & 3.358 \\
\hline $\mathrm{Mn}$ & 0.043 & 0.050 & 0.020 & 0.027 & 0.053 & 0.037 & 0.039 & 0.051 & 0.069 & 0.044 & 0.050 & 0.061 \\
\hline $\mathrm{Mg}$ & 1.485 & 1.084 & 0.951 & 0.909 & 0.561 & 0.649 & 0.965 & 0.441 & 0.585 & 0.594 & 1.150 & 1.100 \\
\hline $\mathrm{Na}$ & 0.019 & 0.027 & 0.033 & 0.018 & 0.023 & 0.050 & 0.044 & 0.044 & 0.018 & 0.008 & 0.022 & 0.018 \\
\hline $\mathrm{K}$ & 1.988 & 1.879 & 1.994 & 2.021 & 1.919 & 1.896 & 1.863 & 1.944 & 1.900 & 1.901 & 1.800 & 1.868 \\
\hline $\mathrm{OH}^{*}$ & 3.459 & 3.635 & 3.234 & 3.289 & 3.554 & 3.543 & 4.000 & 2.941 & 3.311 & 3.373 & 3.726 & 3.890 \\
\hline $\mathrm{F}$ & 0.541 & 0.308 & 0.766 & 0.711 & 0.437 & 0.448 & - & 1.059 & 0.652 & 0.591 & 0.268 & 0.103 \\
\hline $\mathrm{Cl}$ & - & 0.057 & - & - & 0.009 & 0.008 & - & - & 0.038 & 0.036 & 0.006 & 0.007 \\
\hline Total & 19.703 & 19.454 & 19.536 & 19.566 & 19.346 & 19.555 & 19.448 & 19.530 & 19.459 & 19.456 & 19.405 & 19.529 \\
\hline
\end{tabular}

* $\mathrm{H}_{2} \mathrm{O}$ content calculated on the basis of ideal stoichiometry 
served (Fig. 3). The main substitutions are $\mathrm{Fe} \mathrm{Mg}_{-1}$ and AlAl $\mathrm{Mg}_{-1} \mathrm{Si}_{-1}$.

Biotites from the migmatites $\left(\mathrm{X}_{\mathrm{Fe}}=0.62-0.98\right)$ show chemical composition similar to biotites from the metagranites $\left(\mathrm{X}_{\mathrm{Fe}}=0.62-0.80\right)$. The studied samples exhibit rather good negative correlation of $\mathrm{Ba}$ with $\mathrm{Rb}$ contents and $\mathrm{FeO} /(\mathrm{FeO}+\mathrm{MgO})$ ratio in the rock and with $\mathrm{X}_{\mathrm{Fe}}$ in the biotite. The increase in $\mathrm{X}_{\mathrm{Fe}}$ is accompanied by a decrease in $\mathrm{Ti}$ and an increase in $\mathrm{F}$ of the biotite. The contents of tetrahedral Al do not change significantly. The data suggest that the chemical composition of the biotites is determined by $\mathrm{Fe} \mathrm{Mg}_{-1}$ and $\mathrm{TiR} \mathrm{Al}_{-2}$ (where $\mathrm{R}$ represents the sum of the divalent cations in the octahedral site) substitutions. Tschermak substitution AlAl $\mathrm{Mg}_{-1} \mathrm{Si}_{-1}$ is not present.

\section{Whole-rock geochemistry and Nd isotopic compositions of metagranites and migmatites}

\subsection{Metagranites}

The metagranites and migmatites of each of the crystalline complexes have very similar whole-rock chemical compositions (Tab. 4). Metagranites from both the complexes show similar subalkaline geochemical characteristics $\left(\mathrm{K}_{2} \mathrm{O}+\mathrm{Na}_{2} \mathrm{O}=7.2-8.8\right.$ wt. \%) and they represent relatively chemically homogeneous rock association with $\mathrm{SiO}_{2}$ contents ranging from 68 to 76 wt. \%. According to the $\mathrm{P}-\mathrm{Q}$ classification (Debon and Le Fort 1983), the collected samples from both the complexes correspond mostly to granites and only one (sample 2) is adamellite (Fig. 4a). On the basis of the geochemistry, the rocks can be classified as subaluminous to peraluminous $(\mathrm{A} / \mathrm{CNK}$ $=1.0-1.3)$, highly potassic to shoshonitic (Fig. $4 \mathrm{~b})$ with $\mathrm{K}_{2} \mathrm{O} / \mathrm{Na}_{2} \mathrm{O}$ ratios between 1.4 and 2.4. The binary plots of silica vs. selected oxides/elements exhibit negative correlations of $\mathrm{SiO}_{2}$ with $\mathrm{Ba}, \mathrm{Sr}, \mathrm{Zr}, \mathrm{La}, \mathrm{Ce}$ and $\mathrm{Mg}$ (Fig. 6). Compared to the values typical of the upper continental crust (Taylor and McLennan 1995), the metagranites are low in $\mathrm{Ba}, \mathrm{Nb}, \mathrm{Ta}, \mathrm{Sr}, \mathrm{Hf}, \mathrm{Zr}$, Ti and high in $\mathrm{Cs}, \mathrm{Rb}, \mathrm{Th}$, $\mathrm{U}, \mathrm{K}$, HREE and $\mathrm{Y}$ contents (Fig. 5a-b). Relatively low concentrations of $\mathrm{Be}(0-5 \mathrm{ppm})$ are typical of all the migmatites and metagranites. The REE contents range from 50 to $191 \mathrm{ppm}$.

The chondrite-normalized REE trends are similar for all analyses, deviations can be seen only in the samples from Rabuňka and Králický Sněžník (Tabs 2 and 4), which are low in total REE contents (65 and $50 \mathrm{ppm}$, respectively). The normalized REE patterns (Fig. 5c) with distinct negative europium anomaly $\left(\mathrm{Eu} / \mathrm{Eu}^{*}=0.2-0.5\right)$ are relatively flat in the HREE region and exhibit distinct fractionation of the LREE $\left(\mathrm{La}_{\mathrm{N}} / \mathrm{Yb}_{\mathrm{N}}=2-6\right)$.

\subsection{Migmatites}

Alkali $\left(\mathrm{Na}_{2} \mathrm{O}+\mathrm{K}_{2} \mathrm{O}\right)$ contents of the studied migmatites range from 6.7 to $8.4 \mathrm{wt}$. \% (subalkaline geochemical characteristics) and $\mathrm{SiO}_{2}$ content is high (71-78 wt. \%).
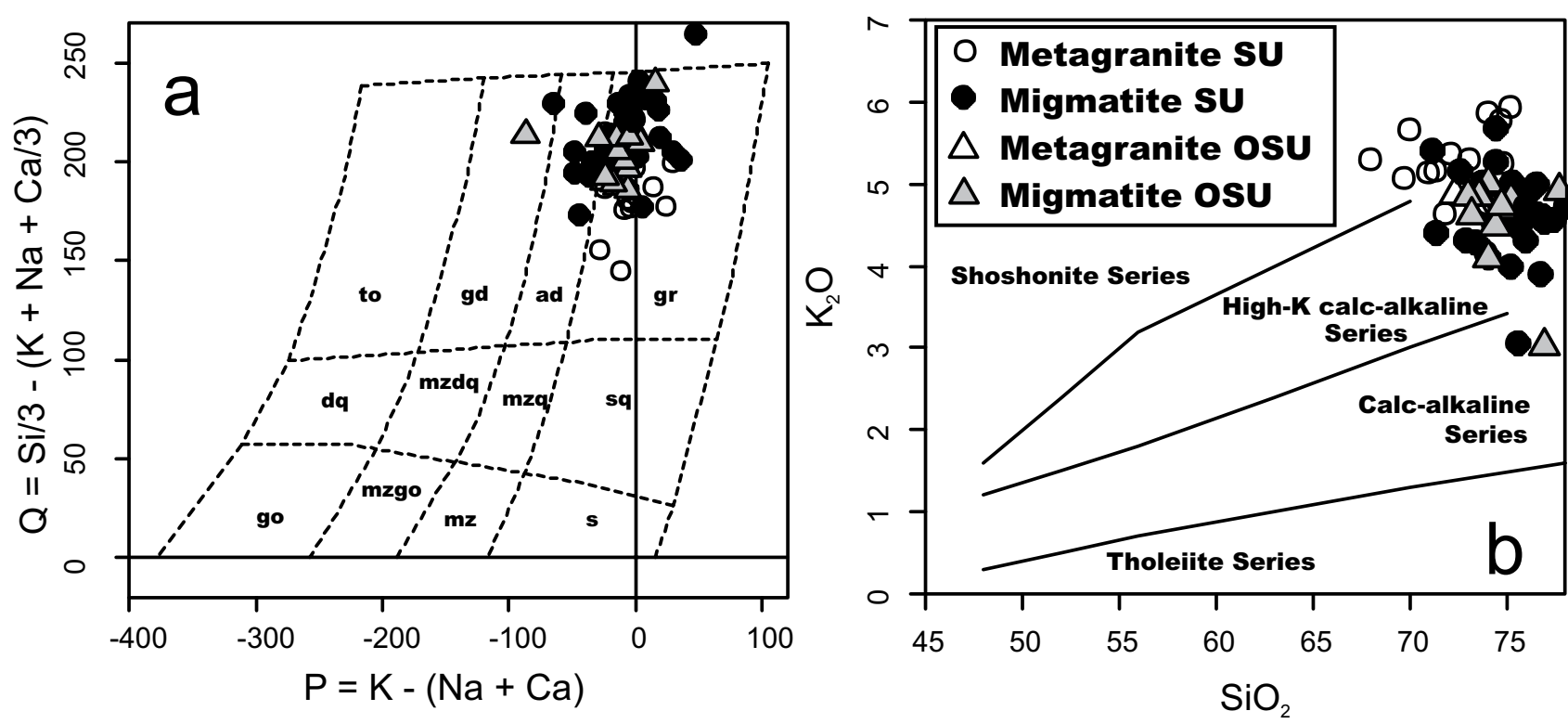

Fig. 4 Chemical classification of plutonic rocks applied to the studied metagranites and migmatites (Svratka Unit $=$ SU, Orlice-Sněžník Unit $=$ OSU). $\mathbf{a}-\mathrm{P}-\mathrm{Q}$ plot (Debon and Le Fort 1983) and $\mathbf{b}-\mathrm{SiO}_{2}-\mathrm{K}_{2} \mathrm{O}$ plot (Peccerillo and Taylor 1976). go = gabbro, diorite, anorthosite; mzgo = monzogabbro, monzodiorite; $\mathrm{mz}=$ monzonite; $\mathrm{s}=$ syenite; $\mathrm{dq} \mathrm{qtz}=$ diorite, quartz gabbro, quartz anorthosite; mzdq qtz = monzodiorite, qtz monzogabbro; mzq = quartz monzonite; $\mathrm{sq}=$ quartz syenite; to = tonalite, trondhjemite; $\mathrm{gd}=$ granodiorite, granogabbro; ad $=$ adamellite; $\mathrm{gr}=$ granite . 
Tab. 4 Representative major- and trace-element whole-rock chemical analyses (wt. \% and ppm, respectively)

\begin{tabular}{|c|c|c|c|c|c|c|c|c|c|c|}
\hline Sample No. & 1 & 2 & 3 & 5 & 6 & 7 & 8 & 11 & 12 & 13 \\
\hline $\mathrm{SiO}_{2}$ & 75.87 & 73.95 & 74.07 & 71.32 & 73.38 & 72.37 & 75.63 & 74.48 & 75.26 & 73.69 \\
\hline $\mathrm{TiO}_{2}$ & 0.13 & 0.24 & 0.26 & 0.30 & 0.25 & 0.29 & 0.14 & 0.08 & 0.13 & 0.23 \\
\hline $\mathrm{Al}_{2} \mathrm{O}_{3}$ & 12.86 & 13.67 & 13.44 & 14.98 & 13.54 & 14.16 & 13.96 & 13.60 & 13.09 & 13.66 \\
\hline $\mathrm{Fe}_{2} \mathrm{O}_{3}$ & 1.72 & 2.45 & 1.89 & 2.36 & 2.49 & 2.36 & 1.28 & 1.28 & 1.72 & 2.12 \\
\hline $\mathrm{MnO}$ & 0.04 & 0.03 & 0.02 & 0.04 & 0.04 & 0.05 & 0.03 & 0.06 & 0.03 & 0.03 \\
\hline $\mathrm{Cr}_{2} \mathrm{O}_{3}$ & 0.00 & 0.00 & 0.00 & 0.00 & 0.01 & 0.01 & 0.00 & 0.00 & 0.00 & 0.00 \\
\hline $\mathrm{MgO}$ & 0.19 & 0.43 & 0.52 & 0.59 & 0.40 & 0.46 & 0.33 & 0.13 & 0.19 & 0.37 \\
\hline $\mathrm{CaO}$ & 0.40 & 0.79 & 0.87 & 1.11 & 1.15 & 1.34 & 0.75 & 0.57 & 0.59 & 1.02 \\
\hline $\mathrm{Na}_{2} \mathrm{O}$ & 2.92 & 3.04 & 2.79 & 3.03 & 2.98 & 2.93 & 3.60 & 2.52 & 2.87 & 2.89 \\
\hline $\mathrm{K}_{2} \mathrm{O}$ & 4.76 & 4.16 & 4.75 & 5.15 & 4.69 & 4.88 & 3.06 & 5.68 & 4.80 & 4.85 \\
\hline $\mathrm{P}_{2} \mathrm{O}_{5}$ & 0.26 & 0.23 & 0.20 & 0.21 & 0.16 & 0.21 & 0.23 & 0.19 & 0.21 & 0.17 \\
\hline LOI & 0.9 & 0.8 & 0.9 & 0.8 & 0.9 & 0.9 & 1.0 & 1.3 & 1.0 & 0.8 \\
\hline Total & 100.1 & 99.8 & 99.7 & 99.9 & 100.0 & 100.0 & 100.0 & 99.9 & 99.9 & 99.8 \\
\hline $\mathrm{Ba}$ & 71.0 & 163 & 495.6 & 500.0 & 294.2 & 512.3 & 151.2 & 131.4 & 118.8 & 393.2 \\
\hline $\mathrm{Co}$ & 1.3 & 2.1 & 2.2 & 2.6 & 2.4 & 3.3 & 2.9 & 1.1 & 1.1 & 2.4 \\
\hline $\mathrm{Cu}$ & 1.7 & 2.6 & 4.1 & 7.8 & 2.4 & 3.3 & 10.2 & 3.6 & 2.1 & 4.9 \\
\hline $\mathrm{Ni}$ & 2.6 & 3.0 & 4.6 & 5.2 & 5.3 & 5.3 & 5.3 & 1.9 & 2.1 & 3.5 \\
\hline $\mathrm{Rb}$ & 440.3 & 307.3 & 205.8 & 257.1 & 194.9 & 199.5 & 126.8 & 324.3 & 293.7 & 183.4 \\
\hline $\mathrm{Sr}$ & 17.9 & 48.0 & 126.4 & 112.3 & 59.7 & 90.7 & 177.3 & 36.9 & 23.2 & 67.3 \\
\hline V & 5 & 11 & 17 & 23 & 15 & 23 & 12 & $<8$ & 8 & 13 \\
\hline $\mathrm{Sn}$ & 8 & 6 & 3 & 5 & 3 & 3 & 4 & 12 & 7 & 3 \\
\hline $\mathrm{Zn}$ & 4 & 57 & 23 & 23 & 31 & 30 & 20 & 25 & 26 & 42 \\
\hline As & 0.9 & 24.5 & 5.0 & 33.1 & 13.9 & 4.0 & 0.9 & 2.9 & 1.0 & 1.4 \\
\hline $\mathrm{U}$ & 4.2 & 4.1 & 4.1 & 4.4 & 3.5 & 3.0 & 3.0 & 5.5 & 3.6 & 2.2 \\
\hline $\mathrm{Nb}$ & 12.0 & 13.5 & 9.4 & 10.9 & 9.0 & 10.2 & 6.8 & 7.7 & 10.1 & 8.1 \\
\hline Mo & 0.1 & 0.4 & 0.2 & 0.5 & 0.2 & 0.3 & 0.1 & 0.2 & 0.1 & 0.1 \\
\hline Y & 31.4 & 50.3 & 38.2 & 46.5 & 48.4 & 46.6 & 18.3 & 19.6 & 31.8 & 40.0 \\
\hline $\mathrm{Zr}$ & 73.0 & 127.7 & 112.0 & 132.7 & 140.1 & 156.3 & 74.5 & 48.8 & 88.7 & 127.4 \\
\hline $\mathrm{Pb}$ & 1.4 & 8.8 & 5.2 & 9.2 & 12.2 & 5.0 & 3.5 & 5.8 & 3.0 & 6.0 \\
\hline $\mathrm{Cs}$ & 25.1 & 24.0 & 12.3 & 12.6 & 6.4 & 5.8 & 3.9 & 3.5 & 7.3 & 3.9 \\
\hline $\mathrm{Th}$ & 11.5 & 13.7 & 11.0 & 12.9 & 11.9 & 11.9 & 7.0 & 3.0 & 12.7 & 9.1 \\
\hline $\mathrm{Ta}$ & 2.0 & 1.4 & 1.0 & 1.2 & $<0.1$ & $<0.1$ & 0.8 & 0.4 & 0.1 & $<0.1$ \\
\hline Hf & 2.8 & 4.5 & 3.7 & 5.3 & 4.6 & 4.9 & 2.8 & 2.2 & 3.5 & 4.1 \\
\hline $\mathrm{Sc}$ & 4 & $<1$ & 4 & 4 & 6 & 5 & 4 & 4 & 3 & 4 \\
\hline $\mathrm{Au}$ & 0.0007 & 0.0010 & $<0.0005$ & 0.0008 & 0.0010 & 0.0071 & 0.0011 & $<0.0005$ & 0.0010 & 0.0010 \\
\hline $\mathrm{Sb}$ & 0.1 & 0.4 & 0.2 & 0.7 & 0.1 & 0.1 & 0.1 & 0.1 & 0.1 & $<0.1$ \\
\hline $\mathrm{Tl}$ & 0.8 & 0.8 & 0.6 & 0.7 & 0.4 & 0.4 & 0.2 & 0.4 & 0.3 & 0.3 \\
\hline $\mathrm{Bi}$ & 0.1 & 0.2 & 0.1 & 0.2 & 0.1 & 0.1 & 0.1 & 0.1 & 0.1 & 0.2 \\
\hline W & 11.4 & 3.9 & 2.8 & 3.8 & 1.4 & 1.2 & 2.7 & 4.8 & 4.6 & 0.9 \\
\hline $\mathrm{Ga}$ & 21.6 & 23.0 & 17.9 & $<0.5$ & 18.4 & 19.8 & 17.4 & 19.4 & 19.3 & 18.1 \\
\hline $\mathrm{Be}$ & 1.0 & $<0.1$ & $<0.1$ & $<0.1$ & 3.0 & 2.0 & 3.0 & 2.0 & 5.0 & 2.0 \\
\hline $\mathrm{La}$ & 10.5 & 19.8 & 19.1 & 24.1 & 15.8 & 22.9 & 12.7 & 5.0 & 14.8 & 7.6 \\
\hline $\mathrm{Ce}$ & 24.0 & 41.7 & 43.1 & 49.5 & 36.8 & 49.5 & 26.9 & 11.5 & 30.0 & 35.9 \\
\hline $\operatorname{Pr}$ & 2.79 & 4.88 & 5.09 & 5.41 & 4.31 & 6.00 & 3.07 & 1.58 & 3.80 & 2.41 \\
\hline $\mathrm{Nd}$ & 9.2 & 16.4 & 18.2 & 21.1 & 17.0 & 22.4 & 10.7 & 6.4 & 12.3 & 9.6 \\
\hline $\mathrm{Sm}$ & 2.5 & 4.2 & 3.9 & 5.1 & 4.0 & 5.2 & 2.8 & 1.8 & 3.2 & 3.0 \\
\hline $\mathrm{Eu}$ & 0.15 & 0.28 & 0.44 & 0.69 & 0.39 & 0.58 & 0.29 & 0.14 & 0.16 & 0.42 \\
\hline Gd & 2.64 & 5.15 & 4.15 & 5.49 & 4.49 & 4.95 & 2.43 & 1.88 & 3.46 & 3.80 \\
\hline $\mathrm{Tb}$ & 0.61 & 1.23 & 0.99 & 1.08 & 1.15 & 1.18 & 0.50 & 0.50 & 0.87 & 1.01 \\
\hline Dy & 4.86 & 6.98 & 5.59 & 7.61 & 6.71 & 6.95 & 2.71 & 3.31 & 4.93 & 6.00 \\
\hline Ho & 0.99 & 1.61 & 1.20 & 1.61 & 1.47 & 1.50 & 0.62 & 0.66 & 1.01 & 1.26 \\
\hline $\mathrm{Er}$ & 2.92 & 5.18 & 3.48 & 4.38 & 4.91 & 4.51 & 1.68 & 1.99 & 3.02 & 3.82 \\
\hline $\mathrm{Tm}$ & 0.54 & 0.74 & 0.56 & 0.69 & 0.79 & 0.72 & 0.26 & 0.39 & 0.42 & 0.55 \\
\hline $\mathrm{Yb}$ & 3.11 & 4.57 & 3.40 & 4.21 & 4.67 & 4.19 & 1.55 & 2.31 & 2.74 & 3.25 \\
\hline $\mathrm{Lu}$ & 0.43 & 0.61 & 0.51 & 0.53 & 0.74 & 0.57 & 0.22 & 0.33 & 0.37 & 0.47 \\
\hline $\mathrm{Eu} / \mathrm{Eu}^{*}$ & 0.18 & 0.18 & 0.33 & 0.40 & 0.28 & 0.35 & 0.34 & 0.23 & 0.15 & 0.38 \\
\hline $\mathrm{LaN} / \mathrm{YbN}$ & 2.28 & 2.92 & 3.79 & 3.86 & 2.28 & 3.68 & 5.52 & 1.46 & 3.64 & 1.58 \\
\hline $\mathrm{A} / \mathrm{CNK}$ & 1.20 & 1.25 & 1.19 & 1.19 & 1.12 & 1.13 & 1.32 & 1.20 & 1.19 & 1.15 \\
\hline $\mathrm{K}_{2} \mathrm{O} / \mathrm{Na}_{2} \mathrm{O}$ & 1.63 & 1.37 & 1.70 & 1.70 & 1.57 & 1.67 & 0.85 & 2.25 & 1.67 & 1.68 \\
\hline
\end{tabular}



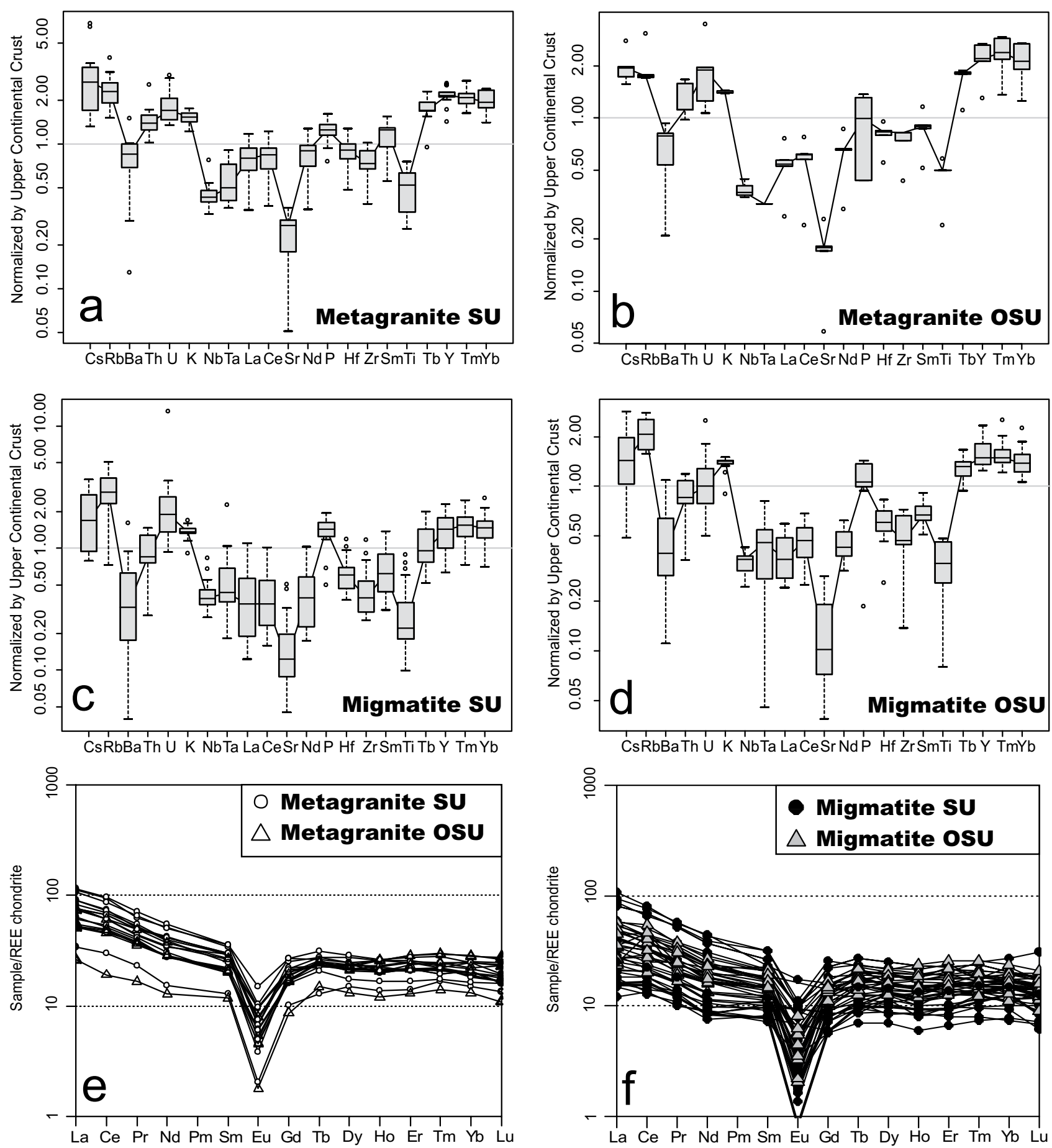

Fig. 5 Chemical composition of the studied metagranites (a-b, e) and migmatites (c-d, f). a-e - Box and whiskers plots normalized by Upper Continental Crust (Taylor and McLennan 1995), and e-f - Chondrite-normalised REE patterns (Boynton 1984). The same symbols as in Fig. 3.

They can be classified as medium-K calc-alkaline to shoshonitic rocks with a $\mathrm{K}_{2} \mathrm{O} / \mathrm{Na}_{2} \mathrm{O}$ ratio ranging between 0.7 and 3.1. All the studied samples are subaluminous to peraluminous $(\mathrm{A} / \mathrm{CNK}=1.0-1.6)$. In the $\mathrm{P}-\mathrm{Q}$ diagram (Debon and Le Fort 1983), migmatites show a wider range chemical composition than metagranites (Fig. 4a).
Compared to the values typical of the upper crust (Taylor and McLennan 1995), the migmatites are low in $\mathrm{Ba}, \mathrm{Nb}, \mathrm{Ta}, \mathrm{Sr}$, LREE, $\mathrm{Zr}$ and $\mathrm{Ti}$, and high in $\mathrm{Cs}, \mathrm{Rb}$, Th, K, P, HREE and Y contents (Fig. 5d-e). The plots of silica vs. selected oxides/elements exhibit a negative correlations of $\mathrm{SiO}_{2}$ with $\mathrm{Al}_{2} \mathrm{O}_{3}, \mathrm{MgO}, \mathrm{TiO}_{2}, \mathrm{CaO}, \mathrm{FeO}$, 

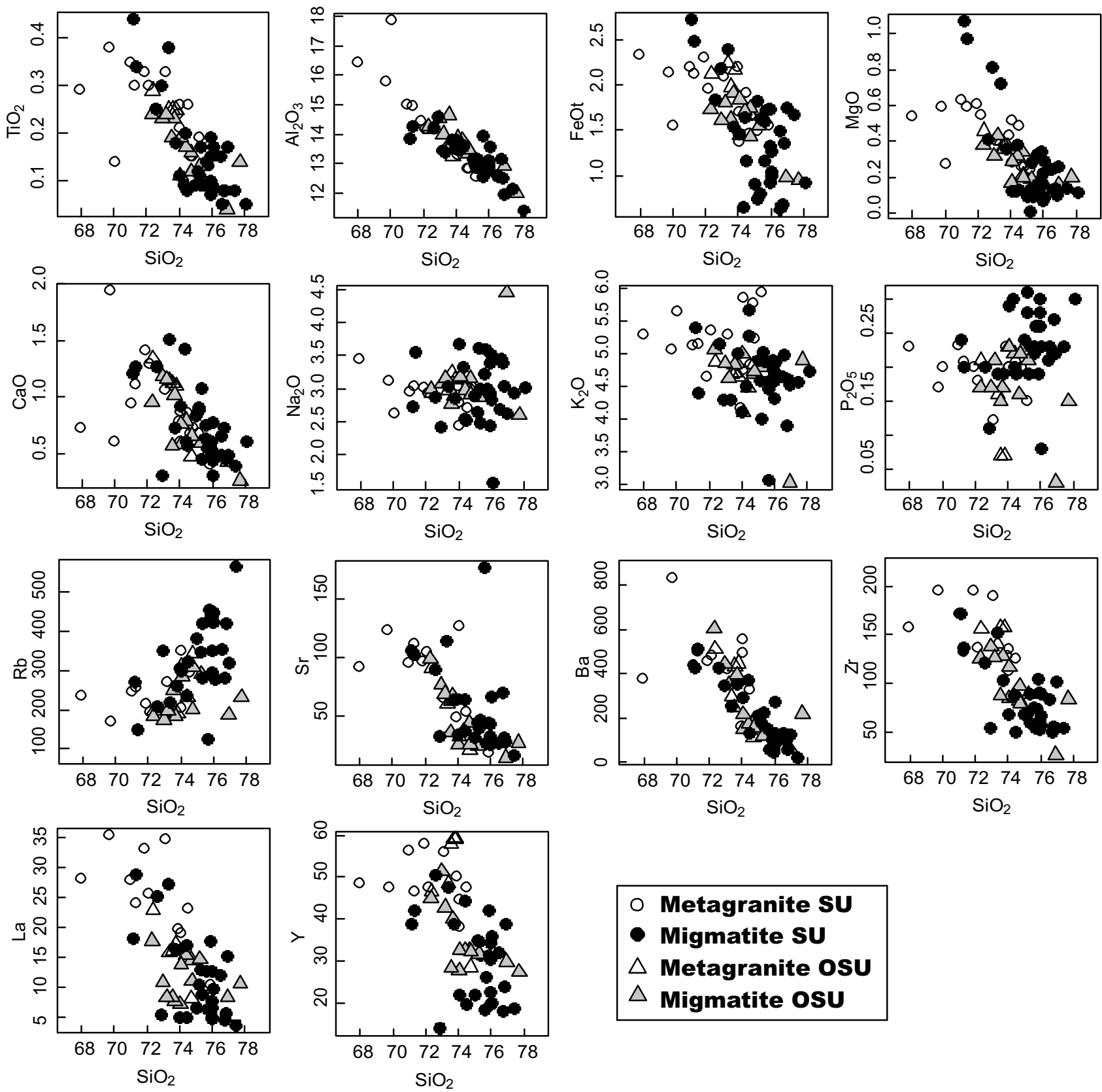

Fig. 6 Variation diagrams for selected major, minor and trace elements in migmatites and metagranites (same symbols as in Fig. 3).

$\mathrm{Ba}, \mathrm{Sr}, \mathrm{Zr}$, Hf, Y, La and Ce (Fig. 6). The contents of B in the migmatites (analyzed in only 4 samples) range from 8 to $469 \mathrm{ppm}$ and are correlated with the occurrence of tourmaline. The total REE contents range from 38 to $142 \mathrm{ppm}$ and their normalized trends are similar for all the samples. The REE curves are relatively flat in the HREE region (Fig. 5e) and exhibit a carious degree of the LREE/HREE fractionation $\left(\mathrm{La}_{\mathrm{N}} / \mathrm{Yb}_{\mathrm{N}}=2-9\right)$. The rocks are also characterized by a negative europium anomaly $\left(\mathrm{Eu} / \mathrm{Eu}^{*}=0.1-0.9\right)$. Migmatites in both complexes have similar REE contents (e.g. an average content of La of c.12 ppm).
On the basis of our geochemical data, it is obvious that migmatites from the SU exhibit a significantly higher degree of fractionation than those from the OSU (Figs 4 and 5).

\subsection{Nd isotopic geochemistry}

The initial $\varepsilon_{515}^{N d}$ values for rocks from the SU refer to the crystallization ages determined on zircons from metagranites (Schulmann et al. 2005). The same age was used to age correct the $\mathrm{Nd}$ isotopic data for the migmatites, because the anatexis should be similar to, or only slightly 
older than, the age of crystallization of the metagranites (Melichar and Hanžl 2003).

The metagranites from the SU and the OSU have overlapping neodymium isotopic compositions $\left(\varepsilon_{515}^{N d}=-5.2\right.$ and -5.7 for the two samples from the SU versus $\varepsilon_{\mathrm{t}}^{N d}=-3.5$ to -6.5 for the metagranites from the OSU, where $t=$ age of 500-511 Ma; Hegner and Kröner 2000; Lange et al. 2005; Pin et al. 2007). The two-stage Depleted Mantle $\mathrm{Nd}$ model ages $\left(\mathrm{T}_{D M}^{N d}\right)$ calculated for metagranites from the $\mathrm{SU}(1.6 \mathrm{Ga})$ are comparable with the values calculated by Hegner and Kröner (2000), Lange et al. (2005) and Pin et al. (2007) for metagranites from the OSU (1.4 to $1.8 \mathrm{Ga})$.

Two samples of migmatites from the SU differ widely in their neodymium isotopic compositions $\left(\varepsilon_{515}^{N d}=-6.6\right.$ and -11.6), yielding two-stage Depleted Mantle Nd model ages of $\mathrm{T}_{D M}^{N d}=1.7$ and $2.1 \mathrm{Ga}$. Range of isotopic compositions obtained for migmatites (Gierałtów gneisses) from the OSU (Lange et al. 2005; Pin et al. 2007) is relatively wider $\left(\varepsilon_{500}^{N d}=-0.3\right.$ to -7.1 , but most of them fall between -3.3 and -5.7), and their $\mathrm{T}_{D M}^{N d}$ range between 1.2 and 3.1 Ga.

The composition of the biotite-rich enclaves (Buriánek 2008) differs from that of diatexites and is characterized by high contents of $\mathrm{MgO}$ (2-4 wt. \%), $\mathrm{FeO}$ (5-22 wt. \%), $\mathrm{K}_{2} \mathrm{O}$ (6-10 wt. \%), $\mathrm{Rb}(1022-1515 \mathrm{ppm})$ and low $\mathrm{Na}_{2} \mathrm{O}$ contents $(0.2-0.9$ wt. \%). Two distinct types of enclaves can be distinguished (Buriánek, 2008): (1) biotite-rich enclaves with muscovite, characterized by high contents of REE, Y, Th, U, Zr, Hf and P, and (2) biotite to muscovite-biotite enclaves with occasional garnet or tourmaline characterized by low contents of REE, Y, Th, $\mathrm{U}, \mathrm{Zr}$, Hf and P.

\section{Microstructures}

The migmatites and metagranites from both the units were originally similar in composition. Nevertheless, their evolution (especially during the Variscan orogeny) was slightly different (Štípská et al. 1998; Štípská 1999; Schulmann et al. 2005; Zavřelová et al. 2006). On the basis of our microstructural observations of the coarsegrained, porphyritic metagranites and migmatites from both units, we consider the distinct finite strain patterns, prevailing temperatures and deformation mechanisms important during later stages of their evolution.

\subsection{Quartzo-feldspathic rocks of the Svratka Unit}

In general, the principal fabric detected in the rocks of the $\mathrm{SU}$ is represented by $\sim \mathrm{NW}-\mathrm{SE}$ regional metamorphic foliation dipping steeply to moderately to the $\mathrm{NE}$ and to $\mathrm{SW}$ in the south-eastern most tip of the unit. These foliations have been folded into a large anticlinal structure plunging to the NNW in the NW part of the unit. Foliations bear well-developed, gently to moderately plunging, NW-SE stretching lineation and are also roughly parallel to the contacts with adjacent geological units (Verner et al. this volume). The initial stages of deformation and recrystallization (predominantly along fractures, crystal boundaries and other instabilities) were heterogeneous. In relics, relevant microstructures of less deformed parts of the metagranite bodies exhibit fractured irregular quartz and $\mathrm{K}$-feldspar aggregates retaining their original magmatic shapes. A lot of these crystals exhibit magmatic zoning (Melichar 1991). The lattice-preferred orientation (LPO) of newly recrystallized isometric grains (up to $0.2 \mathrm{~mm}$ in size) is obvious and sharply discordant to the regional fabric described above. The aggregates of muscovite and biotite are recrystallized, having euhedral shapes without traces of internal deformation. Rarely preserved migmatites at this stage of deformation indicate some relicts of the typical primary migmatite texture in the leucosome (Vernon and Johnson 2000). In this case, we noticed some characteristic textures between crystals that precipitated from the melt (e.g., "bell-shaped" crystal size distributions in the rocks and crystal faces of feldspar aggregates with simple twinning; Fig. 7a).

On the other hand, different microstructures can be seen in the more deformed parts of the metagranites and migmatites. The majority of minerals in metagranites were dynamically recrystallized, especially the feldspars, into a mosaic of euhedral to subhedral isometric sub-grains (up to $0.3 \mathrm{~mm}$ in size). New aggregates with high-angle sub-grain boundaries (see Fig. 7b) occur. Their LPO is relatively strong, oriented sub-parallel to the regional fabric (Fig. 8b). Under the same conditions, migmatites produced interlobate, slightly elongated new sub-grains of quartz (0.3-0.8 $\mathrm{mm}$ in size), fully recrystallized aggregates of micas and small, new isometric subgrains around igneous feldspar crystals (Fig. 7c).

\subsection{Quartzo-feldspathic rocks of the Orlice-Sněžník Unit}

The oldest regional structures (of pre-Variscan age?) of the OSU that were formed under HT conditions connected with extensive anatexis $\left(\mathrm{D}_{1}\right.$ event; Přikryl et al. 1996) are relatively rare. The superimposed fabrics - flatlying, medium-temperature foliations associated with $\mathrm{N}-\mathrm{S}$ stretching lineations $\left(\mathrm{D}_{2}\right.$ stage $)$ probably reflect the Variscan exhumation history of the OSU (Štípská et al. 2001). This well-developed second phase was associated with an intense ( $\approx$ mylonitic) deformation of the previous quartzo-feldspathic rocks. Residual feldspar grains are rounded and fractured, in addition providing evidence 

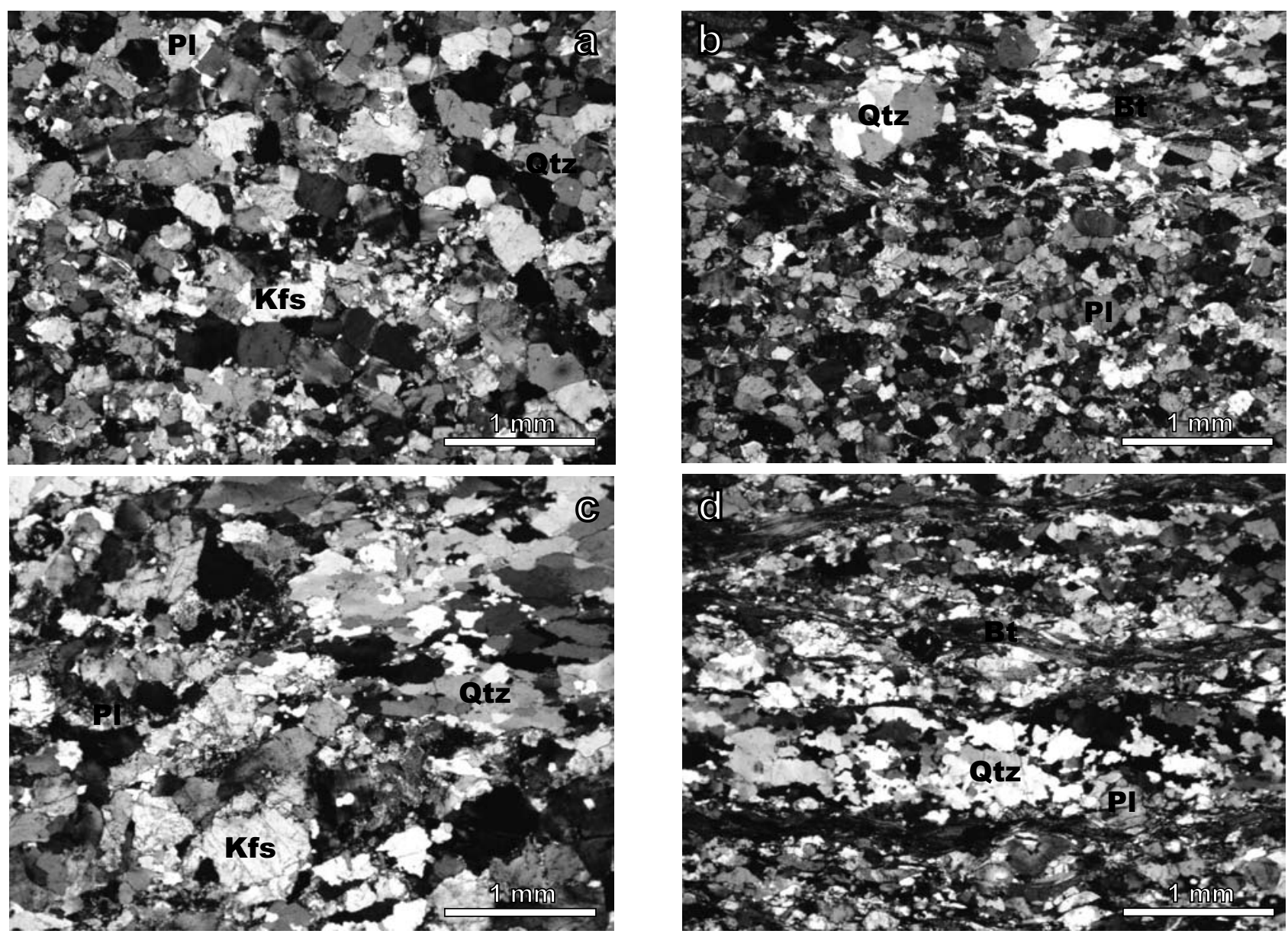

Fig. 7. Photomicrographs of typical samples of the studied rocks. a-Relict microstructures of the leucosome in a pre-Variscan migmatite; the crystal shapes reflect crystallization in a melt (locality: Zkaměnelý Zámek, Svratka Unit). b - Dynamically recrystallized K-feldspar porphyroclast in metagranite; new grains have a strong shape-preferred orientation, which defines the regional fabric (Rabuňka, Svratka Unit). c - Partly recrystallized and deformed migmatite; interlobate new sub-grains of quartz, and small new isometric sub-grains deflected around feldspar crystals originating from the melt (Dalečín, Svratka Unit). d - Medium-temperature mylonite fabrics in a metagranite (Hoblovna, Orlice-Sněžník Unit).

for ductile deformation along their boundaries. Biotite and muscovite aggregates were deformed plastically into stripes and have recrystallized to fine grains drawn out into a metamorphic fabric. Quartz was separated into thin bands (up to $5 \mathrm{~mm}$ thick) and new sub-grains with interlobate, slightly elongated shapes were observed (Fig 7d).

\section{Discussion}

The genesis of the studied metagranites has been discussed previously by many authors (Fischer 1935; Svoboda 1966; Opletal et al. 1980; Don et al. 1990; Oliver et al. 1993; Cymerman 1997; Pin et al. 2007) and most of the workers concluded that their origin was magmatic. The metagranites and migmatites from the SU and the $\mathrm{OSU}$ are peraluminous, as indicated by the presence of sillimanite, tourmaline and garnet and confirmed by high $\mathrm{A} / \mathrm{CNK}$ ratios. Their geochemical character is similar to that of the melts derived from metapelites (i.e. from rocks rich in clay minerals and poor in feldspars, Fig. 8; Sylvester 1998). Crustal anatexis is responsible for the production of peraluminous granitic melt and therefore plays a key role in crustal differentiation processes (Holtz 1989; Brown et al. 1995).

A metatexite is characterized by the presence of compositional banding of a deformed granitic melt (leucosome) and a biotite-rich melanosome. The degree of geochemical fractionation in leucosome is probably low, depending mainly on the degree of partial melting (the mobility of the melt is insignificant). Even though, from a geochemical point of view, the studied migmatites represent a rather homogeneous rock group, they are not a product of a similar type of melting and crystallization in both units. This can be shown on the heterogeneity 


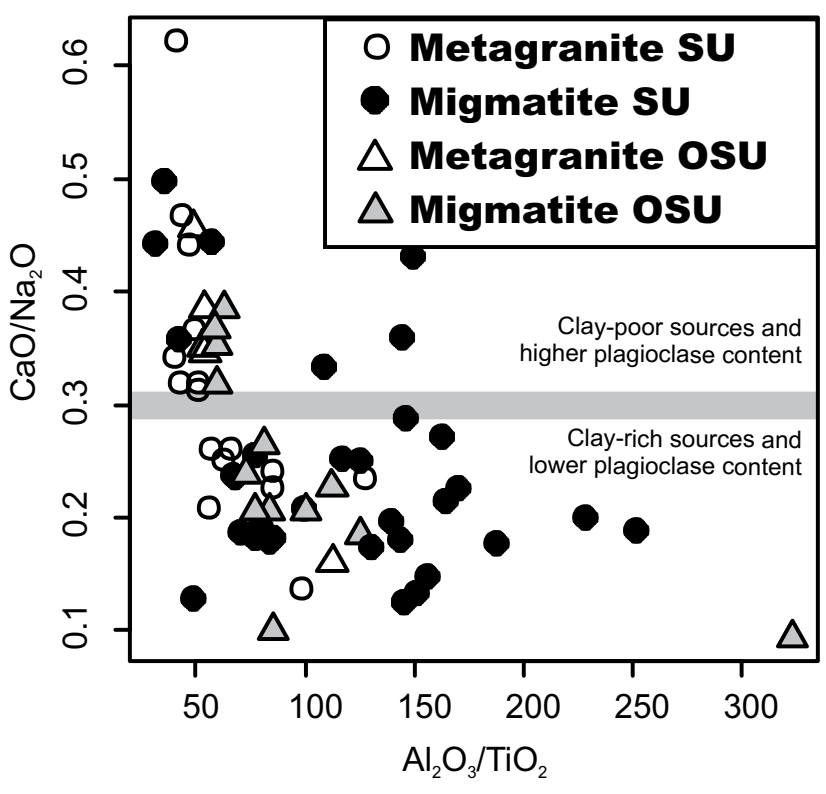

Fig. $8 \mathrm{CaO} / \mathrm{Na}_{2} \mathrm{O}-\mathrm{Al}_{2} \mathrm{O}_{3} / \mathrm{TiO}_{2}$ plot (modified from Sylvester 1998).

of their textures and on the diffuse intrusive contact of small younger veins and patches of tourmaline-bearing and two-mica leucosome (granitic melt) with older muscovite-biotite migmatites in the SU. These metagranites represent a B-rich melt generated in migmatites during a subsequent partial melting event. The new geochronological data (zircon ${ }^{206} \mathrm{~Pb} / 238 \mathrm{U}$ ages, Lange et al. 2002, 2003, 2005) have documented Variscan anatectic processes (364-341 Ma) in OSU migmatites. The $\mathrm{Rb}-\mathrm{Sr}$ and ${ }^{40} \mathrm{Ar} /{ }^{39} \mathrm{Ar}$ dating mostly provided cooling ages for orthogneisses (340-330 Ma; e.g. Lange et al. 2005). On the contrary, Żelaźniewicz et al. (2006) interpreted migmatitization as Late Cambrian-Early Ordovician. In our view, the Cambrian-Ordovician migmatized complex was to a similar extent affected also by the Variscan migmatization.

The $\mathrm{X}_{\mathrm{Fe}}$ values and the $\mathrm{F}$ contents in the biotite are positively, and the Ti concentrations are negatively, correlated with the degree of geochemical fractionation of the diatexites (Fig. 3c-d). In spite of the metamorphic recrystallization, biotites in the migmatites thus still reflect the degree of geochemical fractionation of the parental melt. Described correlation between $\mathrm{X}_{\mathrm{Fe}}$ and Ti in biotite and geochemical composition of the whole rocks (e.g. $\mathrm{Ba}, \mathrm{SiO}_{2}$ ) is typical of magmatic biotite crystallizing from peraluminous granitic melt (Holtz and Johannes 1991; Villaseca and Barbero 1994). The behaviour of biotite in the samples suggests that the chemical composition changed throughout the recrystallization in a relatively chemically isolated system.

On the other hand, the higher $\mathrm{X}_{\mathrm{Fe}}$ values are correlated with the lower concentrations of $\mathrm{F}$ in the biotites from the metagranites (Fig. 3a-b). However, their chemical composition (for example $\mathrm{X}_{\mathrm{Fe}}$ ) reflects geochemical fractionation of the peraluminous melt. The Ti concentrations in the biotites are similar in all the samples and do not depend on the $\mathrm{X}_{\mathrm{Fe}}$ or geochemical fractionation of the original melt. Low variability in biotite chemistry probably reflects lower degree of fractionation of the parental melt. Nevertheless, the Ti contents are lower in the biotites formed as a result of partial replacement of garnet grains.

Metagranites and migmatites in both complexes originated by melting of a similar protolith and evolved by analogous processes. The leucosome of the migmatites was geochemically fractionated (e.g. Rb, Ba) to a higher degree than metagranite. This can be explained as a result of variable degrees of partial melting of similar parental metasediments. The evolution of metagranites and migmatites was a polyphase event, but the original relations between the intrusions and migmatitization were eliminated to a larger extent by subsequent metamorphic recrystallization. Nevertheless, the substantial geochemical similarity shows that they were all derived from a similar source. Therefore, most of the samples should not be referred to as metatexite but rather as diatexite with a variable degree of geochemical fractionation.

In general, melting of the thickened continental crust leads to the generation of migmatite domes with diatexite in the central part, which are enveloped by metatexite and higher-grade metamorphic rocks (Vanderhaeghe 2001). Analogous model may be probably suitable for the Cadomian origin of both the studied units; however the primary field relations were obscured by Variscan thrusting and deformation.

Similar peraluminous metagranitoids are widespread throughout the Cambro-Ordovician Lugian magmatic province, also including the Jizerské hory and Krkonoše Mts. (Kröner et al. 2000). According Kröner et al. (2000), the Cambro-Ordovician Lugian granitoids were formed in an Andean-type tectonic setting and are probably related to subduction of the Tornquist Ocean. On the other hand, Pin et al. (2007) interpreted Cambro-Ordovician Lugian granitoids as anorogenic and explained the generation of large volumes of felsic magmas by a combination of hot extensional tectonic regime with the widespread availability of fertile lithologies in the lower crust.

The initial $\varepsilon_{515}^{N d}$ values and $\mathrm{Nd}$ model ages from two samples of the OSU metagranites correspond to those obtained by Hegner and Kröner (2000) and Lange et al. (2005) from the same unit. The range of negative $\varepsilon_{\mathrm{i}}^{N d}$ values can be interpreted as an evidence for isotopically uniform crustal sources with Mesoproterozoic to Palaeoproterozoic crustal residence ages. On the basis of the isotopic data, Bröcker et al. (2003) considered that migmatites and metagranites from OSU were derived from identical source rocks. 
The protolith of the studied metagranitoids was derived from the recycled Palaeoproterozoic crust (Hegner and Kröner 2000). The oldest geodynamic event was connected with the late Cadomian orogeny $(\sim 570-530$ $\mathrm{Ma})$. The Late Cadomian subduction processes on the periphery of Gondwana were followed by extensive magmatic activity related to crustal extension and wrench dominated tectonics (for a general review, see Linnemann et al. 2008). Shortly after the Cadomian event, a polyphase opening of the Rheic Ocean took place (Linnemann et al. 2008). The emplacement of the Lower Palaeozoic granite plutons of the Lugian Unit (crystallization ages 520-490 Ma: Kröner et al. 2001; Štípská et al. 2004) represents a final stage in the exhumation phase of the Cadomian active margin. The extensive migmatitization in both units is probably related to Cambrian extension and exhumation of the lower crust. Metagranite samples from the SU (this work) and the OSU (Lange et al. 2005; Pin et al. 2007) usually yield a similar range of $\varepsilon_{515}^{N d}$ values. New data obtained from the SU and the OSU are in good agreement with the suggestion of Pin et al. (2007) that the Cambro-Ordovician plutonic activity in the Lugian Zone corresponded to partial melting of heterogeneous sedimentary sources containing a mixture of Late Proterozoic and older (predominantly c. $2 \mathrm{Ga}$ ) components. The interpretation of Hegner and Kröner (2000) that the protolith of the studied granitoids was derived from the recycled Palaeoproterozoic crust in combination with a minor juvenile, i.e. mantle-derived component, is less realistic.

The structures along the contacts between metagranites and migmatites indicate that most of the granitic bodies intruded during/after the migmatitization triggered by Cambrian crustal extension and uplift ( $\sim 530 \mathrm{Ma}$; Linnemann et al. 2000).

In addition, all the rocks were affected by the Variscan tectonometamorphic processes under amphibolite-facies conditions (the SU: $580-650^{\circ} \mathrm{C}$ and 6-7 kbar; Buriánek ed. 2009; Tajčmanová et al. 2006 and the OSU between $550-650^{\circ} \mathrm{C}$ and 6-7 kbar; Mazur and Józefiak 1999). During Variscan orogeny, new trends of regional structures were created to form the eastern termination of the Bohemian Massif. Initially, the rocks of the SU were affected by a static recrystallization with the contribution of advected heat from the exhuming hot orogenic root (Moldanubian Zone). The next Variscan event was connected with dynamic regime (e.g., subgrain rotation and recrystallization) during heterogeneous horizontal shearing along the NE part of the exhuming Moldanubian Zone. In contrast, the rocks from the OSU were deformed more intensively and contain high-temperature mylonitic structures with evidence for grain-boundary migration recrystallization, reflecting regional exhumation processes.

\section{Conclusions}

The all studied rocks correspond to products of crustal melting. Metagranites from both the units are very similar in their whole-rock chemical composition and mineral chemistry. Migmatites underwent polyphase metamorphism, possibly also accompanied by multiple episodes of melting. All the studied rock groups bear signs of mutually comparable types of geochemical fractionation (the increase in $\mathrm{SiO}_{2}$ contents is accompanied by a decrease in $\mathrm{Ba}, \mathrm{Sr}, \mathrm{Mg}$ and $\mathrm{Ca}$, and by an increase in $\mathrm{Rb}, \mathrm{X}_{\mathrm{FeO}} \mathrm{W}$, $\mathrm{Be}$ and $\mathrm{Sn}$ ).

Data presented for the Svratka and the Orlice-Sněžník units in the northeastern part of the Bohemian Massif support the conclusion about melting of the local crust during the Cambro-Ordovician metamorphic event (between $c .470$ and $530 \mathrm{Ma}$ ). The earliest event produced a wide range of textural types of migmatites with variable amounts of melt, from metatexites to diatexites or granites with restitic enclaves. Coarse-grained granites are slightly younger, based on the observed granite intrusion in the migmatite. These bodies probably represent melt segregated from the diatexite and emplaced at a higher structural level of the metamorphosed crust. The compositions are most consistent with derivation of these magmas from a single crustal source very similar to the source of migmatites. Extensive migmatization related to emplacement and crystallization of the coarse-grained S-type granitoids in the Svratka and the Orlice-Sněžník units was associated with Cambrian extension and exhumation of the lower crust.

The rock-forming minerals of the studied rocks were affected by deformation and metamorphic recrystallization under $\sim \mathrm{MP}-\mathrm{MT}$ conditions during the Variscan orogenic processes at $\sim 350-330$ Ma. Primarily, the rocks of the Svratka Unit were affected by static recrystallization but the second Variscan tectonometamorphic event was connected with dynamic recrystallization during horizontal shearing along the exhuming Moldanubian Zone.

By comparison, the rocks of the Orlice-Sněžník Unit were deformed more intensively during the Variscan orogenic processes as the high-temperature mylonitic structures with evidence for grain-boundary migration recrystallization are still preserved. In spite of different Variscan overprint, a number of chemical and petrological signatures inherited from the Cadomian evolution are still preserved in rocks of the Svratka and the OrliceSněžník units. The two can be very well correlated based on chemical and petrological data and they seem to be parts of a single Cadomian geological unit incorporated into the Variscan structure in the hangingwall of the Moldanubicum. 
Acknowledgements The authors would like to thank T. Oberc-Dziedzic and an anonymous reviewer for a critical review of the manuscript. R. Čopjaková is thanked for the electron-microprobe assistance. We are grateful to V. Erban for his comments and for measurements of neodymium isotopes. This work was conducted with the financial aid of the Czech Ministry of Environment, Project No. 6352: Correlation of Lithologically Contrasting Rocks from the Crystalline Units on the NE boundary of Moldanubicum. We would like to thank the Czech Science Foundation (GAČR) for the allocation of grant No. 205/05/0245, which enabled us to investigate the Králický Sněžník region.

Electronic supplementary material. The GPS coordinates of the studied samples, and the table of the whole-rock geochemical data (Tab. 4) are available online at the Journal web site (http://dx.doi.org/10.3190/jgeosci.049).

\section{References}

BOynton WV (1984) Cosmochemistry of the rare earth elements: meteorite studies. In: HENDERSON PE (ed) Rare Earth Element Geochemistry. Elsevier, Amsterdam, pp 63-114

Bröcker M, LANGe U, Mezger K, ŻELAŹNIEwicz A (2003) The orthogneisses of the Orlica-Śnieżnik dome (West Sudetes, Poland): $\mathrm{Sr}-\mathrm{Nd}$ isotope characteristics and $\mathrm{Rb}-\mathrm{Sr}$ geochronology. J Czech Geol Soc 48: 25-26

Bröcker M, Klemd R, Cosca M A, Brock W, Larionov AN, Rodionov N (2009) The timing of eclogite facies metamorphism and migmatization in the Orlica-Śnieżnik complex, Bohemian Massif: constraints from a multimethod geochronological study. J Metamorph Geol 27: 385-403

Brown M (1973) The definition of metatexis, diatexis and migmatite. Proc Geol Assoc 84: 371-382

Brown M, Averkin YA, McLellan EL, Sawyer EW (1995) Melt segregation in migmatites. J Geophys Res B 100: 15655-15679

BURIÁNEK D (2008) Mafic enclaves from the diatexite migmatites in the Svratka Crystalline Complex. Acta Mus Moraviae, Sci Geol 93: 137-150

BuRiÁNEK D, ČOPJAKOvÁ R (2008) Tourmaline from the mica schist of the Svratka Crystalline complex. Acta Mus Moraviae, Sci Geol 93: 61-79 (in Czech)

BuRIÁNeK D, NĚMeČKová M, HanžL P (2003) Petrology and geochemistry of the plutonic rocks in the Polička and Zábřeh crystalline units (NE Bohemian Massif). Bull Geosci 78: 9-22

Buriánek D, Hanžl P, Melichar R, Zavřelová A (2006) Origin and evolution metagranite from Svratka Crystalline Complex. Geol výzk Mor Slez v r 2005: 85-88 (in Czech)
Buriánek D, BŘízová E, Čech S, Čurda J, Fürych V, HANŽL P, KirChNer K, LySENKo V, RoštínsKÝ P, RÝdA K, Skácelová D, Skácelová Z, Verner K, Vít J (2009) Basic geological map ČR 1:25000 with explanations, sheet 24-112 Jedlová. Czech Geological Survey, Prague, pp 1-76 (in Czech)

Cymerman Z (1997) Structure, kinematics and evolution of the Orlica-Śnieżnik Dome, Sudetes. Prace Panstwowego Inst Geol 156:1-120

Cymerman Z, Piasecki MAJ Seston R (1997) Terranes and terrane boundaries in the Sudetes, northeast Bohemian Massif. Geol Mag 134: 717-725

Debon F, Le Fort P (1983) A chemical-mineralogical classification of common plutonic rocks and associations. Trans Roy Soc Edinb, Earth Sci 73: 135-149

Don J, Dumicz M, Wojciechowska I, Żelaźniewicz A (1990) Lithology and tectonics of the Orlica-Śnieżnik Dome, Sudetes: recent state of knowledge. Neu Jb Geol Paläontol, Abh 179: 159-188

FisCheR G (1935) Der Bau des Glatzer Schneegebirges. Jahrb Preuss Geol Landesanst 56: 712-732

Gawlikowska E, Opletal M (1997) Králický Sněžník, geological tourist map 1:50 000. Czech Geological Survey - Polish Geological Institute, Prague and Warsaw

Hanžl P, Buriánek D, Čurda J, Fürich V, HrdičKová K, Kirchner K, Lysenko V, Mrnková J, Otava J, PerTOldová J, RoštínskÝ P, RÝdA K, Skácelová Z, Vít J, ZeLENKA P (2008a) Basic geological map ČR 1:25000 with explanations, sheet 14-333 Svratka. Czech Geological Survey, Prague, pp 1-72 (in Czech)

Hanžl P, HrdličKová K, Bešta J, Blažková Š, BŘízová E, Dosbaba M, Fürych V, Kirchner K, KRYŠtofová E, LySEnKo V, Pertoldová J, RoštínskÝ P, RÝda K, SKÁcelová Z, Skácelová D, TajČmanová L, Vít J, ZavŘelová A, ŽÁČKovÁ E (2008b): Basic geological map ČR 1:25000 with explanations, sheet 24-113 Nové Město na Moravě. Czech Geological Survey, Prague, pp 1-62 (in Czech)

HeGNer E, KRÖNER A (2000) Review of Nd isotopic data and xenocrystic and detrital zircon ages from the pre-Variscan basement in the eastern Bohemian Massif: speculations on palinspastic reconstructions. In: Franke W, AltherR R, HaAk V, Oncken O, Tanner D (eds) Orogenic Processes: Quantification and Modelling in the Variscan Belt. Geol Soc London Spec Publ 179: pp 113-129

HoLtz F (1989) Importance of melt fraction and source rock composition in crustal genesis - the example of two granitic suites of northern Portugal. Lithos 24: 21-35

Holtz F, Johannes W (1991) Genesis of peraluminous granites I. Experimental investigations of melt compositions at 3 and $5 \mathrm{~kb}$ and various $\mathrm{H}_{2} \mathrm{O}$ activities. J Petrol 32: 935-958

Inger S, HaRris N (1993) Geochemical constraints on leucogranite magmatism in the Langtan Valley, Nepal Himalaya. J Petrol 34: 345-368 
Jacobsen SB, Wasserburg GJ (1980) Sm-Nd isotopic evolution of chondrites. Earth Planet Sci Lett 50: 139-155

JANOUŠEK, V, FARROW, CM, ERBAN, V (2006) Interpretation of whole-rock geochemical data in igneous geochemistry: introducing Geochemical Data Toolkit (GCDkit). J Petrol 47: 1255-1259

JASTRZĘBSKI M (in print) A Variscan continental collision of the West Sudetes and the Brunovistulian Terrane: a contribution from structural and metamorphic records of the Stronie Formation, the Orlica-Śnieżnik Dome, SW Poland. Int J Earth Sci DOI: 10.1007/s00531-008-0357-5

KRETZ R (1983) Symbols for rock-forming minerals. Amer Miner 68: 277-279

KRIEGSMAN LM (2001) Partial melting, partial melt extraction, and partial back reaction in anatectic migmatites. Lithos 56: 75-96

Kröner A, ŠTíPskÁ P, Schulmann K, JAeckel P (2000) Chronological constraints on the pre-Variscan evolution of the northeastern margin of the Bohemian Massif, Czech Republic. In: Franke W, Altherr R, HaAk V, Oncken O, Tanner D (eds) Orogenic Processes: Quantification and Modelling in the Variscan Belt. Geol Soc London Spec Publ 179: 175-197

Kröner A, Jaeckel P, Hegner E, Opletal M (2001) Single zircon ages and whole rock $\mathrm{Nd}$ isotopic systematics of early Palaeozoic granitoid gneisses from the Czech and Polish Sudetes (Jizerské hory, Krkonoše Mountains and Orlice-Sněžník Complex). Int J Earth Sci 90: 304-324

Kryza R, Pin C, Vielzeuf D (1996) High pressure granulites from the Sudetes (SW Poland): evidence of crustal subduction and collisional thickening in the Variscan belt. J Metamorph Geol 14: 531-544

Lange U, Bröcker M, Mezger K, Don J (2002) Geochemistry and $\mathrm{Rb}-\mathrm{Sr}$ geochronology of a ductile shear zone in the Orlica-Śnieżnik Dome (West Sudetes, Poland). Int J Earth Sci (Geol Rundsch) 91: 1005-1016

Lange U, Bröcker M, Mezger K, Żelaźniewicz A, (2003) The orthogneisses of the Orlica-Śnieżnik Dome (West Sudetes, Poland): Sr-Nd isotope characteristic and geochronology of micas. J Czech Geol Soc 48: 86

Lange U, Bröcker M, Armstrong R, Zelazniewicz A, Trapp E, Mezger K (2005) The orthogneisses of the Orlica-Śnieżnik complex (West Sudetes, Poland): geochemical characteristics, the importance of pre-Variscan migmatization and constraints on the cooling history. J Geol Soc, London 162: 973-984

Liew TC, Hofmann AW (1988) Precambrian crustal components, plutonic associations, plate environment of the Hercynian Fold Belt of central Europe: indicators from a $\mathrm{Nd}$ and Sm isotopic study. Contrib Mineral Petrol 98: 129-138

Linnemann U, Gehmlich M, Tichomirowa MH, Buschmann B, Nasdala L, Jonas P Lützner H, Bombach K (2000) From Cadomian subduction to early Paleozoic rifting: the evolution of Saxo-Thuringia in the margin of Gondwana in the light of single zircon geochronology and basin development (Central European Variscides, Germany). In Franke W, HaAk V, Oncken O, Tanner, D (eds) Orogenic Processes - Quantification and Modeling in the Variscan belt of Central Europe. Geol Soc London Spec Publ 179: pp 131-153

Linnemann U, D‘Lemos R, Drost K, Jeffries T, Gerdes A, Romer RL, SAmson SD, (2008) Cadomian tectonics. In: McCANN T (ed) The Geology of Central Europe, Vol 1 Precambrian and Palaeozoic. Geological Society London, 103-354

LugMair GW, Marti K (1978) Lunar initial ${ }^{143} \mathrm{Nd} /{ }^{144} \mathrm{Nd}$ : differential evolution line of the lunar crust and mantle. Earth Planet Sci Lett 39: 349-357

MAZur S, JózeFiAK D (1999) Structural record of Variscan thrusting and subsequent extensional collapse in the mica schists from vicinities of Kamieniec Zabkowicki, Sudetic Foreland, SW Poland. Ann Soc Geol Pol 69: 1-26

Melichar R (1991) Basic geological map 1:25 000 on the sheet Křižánky. Zpr geol Výzk v Roce 1989, pp 138-140 (in Czech)

Melichar R, Hanžl P (2003) Stop 5 - Svratka. In: KotkovÁ J (ed) Geology Without Frontiers, Excursion Guide, Czech Geological Survey, Prague, pp 55-59

Melichar R, Buriánek D, BŘízová E, Buriánková K, ČUrda J, Fürych V, Hanžl P, Kirchner K, Lysenko V, Mrnková J, RoštínskÝ P, RÝdA K, SKÁcelová Z, Vít J (2008) Explanations to the geological map ČR $1: 25$ 000, sheet 24-111 Sněžné. Czech Geological Survey, Prague, pp 1-58 (in Czech)

Míková J, Denková P (2007) Modified chromatographic separation scheme for $\mathrm{Sr}$ and $\mathrm{Nd}$ isotope analysis in geological silicate samples. J Geosci 52: 221-226

Mísař Z, Dudek A, Havlena V, Weiss J (1983) Geology ČSSR I. SPN, Prague, pp 1-333

Mrázová Š, Břízová E, Buriánek D, Fürych V, Kadlecová R, Kirchner K, Lysenko V, Otava J, Rambousek P, Roštínský P, Skácelová D, Skácelová Z, Vít J, ZELENKA P (2008): Explanations to the geological map ČR $1: 25$ 000, sheet 13-444 Hlinsko. Czech Geological Survey, Prague, pp 1-68 (in Czech)

Oliver GJH, Corfu F, Krogh TE (1993) U-Pb ages from SW Poland: evidence for a Caledonian suture zone between Baltica and Gondwana. J Geol Soc, London 150: 355-369

Opletal M, DomečKa K, Čech S (1980) Geology of the Orlické hory. Academia, Prague, pp 1-202 (in Czech with extended English summary)

Peccerillo A, Taylor SR (1976) Geochemistry of Eocene calc-alkaline volcanic rocks from the Kastamonu area, Northern Turkey. Contrib Mineral Petrol 58: 63-81

Pertoldová J, Buriánek D, Hrdličková K, Čapek D, Čopjaková R, Schulmannová B, Dušek K, Haloda 
J, HanŽl P, KonopÁseK J, KopaČKovÁ V, KoŠUličovÁ M, Malec J, Nahodilová R, Soejono I, Sulovský P, ŠKoda R, ŠTĚdrÁ V, TÁborskÝ Z, TAJČMANOVÁ L, TÝCOVÁ P, Verner K, Veselovský F, Vondrovic L, Vrána S, Zavřelová A, ŽáčKová E, Šrámek J, Melichar R (2007) Investigation of lithologically contrasting rocks in the crystalline units at the NE margin of the Moldanubian Zone - continuation of basic geological mapping $1: 25$ 000. Unpublished report, Czech Geological Survey, Prague, pp 1-333 (in Czech)

Pertoldová J, Týcová P, Verner K, Košuličová M, Pertold Z, Košler J, Konopásek J, Pudilová M (2009) Metamorphic history of skarns, origin of their protolith and implications for genetic interpretation; an example from three units of the Bohemian Massif. J Geosci 54: 101-134

Pin C, Kryza R, Oberc-Dziedzic T, Mazur S, Turniak K, Waldhausrová J (2007) The diversity and geodynamic significance of Late Cambrian (ca. $500 \mathrm{Ma}$ ) felsic anorogenic magmatism in the northern part of the Bohemian Massif: a review based on $\mathrm{Sm}-\mathrm{Nd}$ isotope and geochemical data. In: Linnemann U, NANCE RD, Kraft P, Zulauf G (eds) The Evolution of the Rheic Ocean: From Avalonian-Cadomian Active Margin to Alleghenian-Variscan Collision. Geological Society of America Special Paper 423: 209-229

PIWINSKII AJ 1968. Experimental studies of igneous rock series; central Sierra Nevada batholith, California. J Geol 76: 548-570

Přikryl R, Schulmann K, Melka R, (1996) Perpendicular fabrics in the Orlické Hory orthogneisses (western part of the Orlice-Sněžník Dome, Bohemian Massif) due to high temperature E-W deformational event and late lower temperature N-S overprint. J Czech Geol Soc 41: 156-166

PuPIN JP (1980) Zircon and granite petrology. Contrib Mineral Petrol 73: 207-220

Schulmann K, Kröner A, Wendt I J, Hegner E, Konopásek J, LEXA O, ŠTíPSKÁ P (2005) Chronological constraints on the pre-orogenic history, burial and exhumation of deep-seated rocks along the eastern margin of the Variscan orogen, Bohemian Massif, Czech Republic. Am J Sci 305: 407-448

StÁRKovÁ I, MACEK J (1994) Geological map ČR 1 : 50000 , 24-13 Bystřice nad Pernštejnem. Czech Geological Survey, Prague

StÁrková I, MaceK J, Moupic Z (1996) Geological map of Czech Republic 1:50 000, sheet 24-11, Nové Město na Moravě. Czech Geological Survey, Prague

Stárková I, Opletal M, Adamovič J, MaceK J (1998) Geological map of Czech Republic 1:50 000, sheet 14-33, Polička. Czech Geological Survey, Prague

Stawikowski W (2002) Contacts between high-P eclogites and gneisses in the Śnieżnik Metamorphic Unit, the West Sudetes. Geolines 14: 84-85.
Sylvester PJ (1998) Post-collisional strongly peraluminous granites. Lithos 45: 29-44

Svoboda J (1966) Orlické hory, Kralický Sněžník. In : SvoBODA J (ed) Regional Geology of Czechoslovakia. Part I. The Bohemian Massif. Nakladatelství Československé akademie věd, Prague, pp 257-272 (in Czech)

ŠTíPSKÁ P (1999) Thermomechanical evolution of collisional boundary during Variscan convergence - eastern margin of the Bohemian Massif (examples of the Staré Město Belt and the Thaya Dome). Unpublished PhD. thesis, Charles University, Prague, pp 1-175

ŠTíPSKÁ P, Schulmann K, KRÖNER A (1998) Role of Cambro-Ordovician rifting in Variscan collision at the NE margin of the Bohemian Massif. Acta Univ Carol, Geol 42: 343-334

ŠtíPsKÁ P, Schulmann K, Thompson A B, JeŽEK J, KRÖNER A, (2001) Thermo-mechanical role of a Cambro-Ordovician paleorift during the Variscan collision: the NE margin of the Bohemian Massif. Tectonophysics 332: 239-253

ŠTíPsKÁ P, Schulmann K, Kröner A (2004) Vertical extrusion and middle crustal spreading of omphacite granulite: a model of syn-convergent exhumation (Bohemian Massif, Czech Republic). J Metamorph Geol 22: 179-198

TajČmanová L, Konopásek J, Schulmann K (2006) Thermal evolution of the orogenic lower crust during exhumation within a thickened Moldanubian root of the Variscan belt of Central Europe. J Metamorph Geol 24: 119-134

TAYlor SR, MCLenNAN SM (1995) The geochemical evolution of the continental crust. Rev Geophys 33: 241-265

TurniaK K, MaZur S. WysoczańSKi R. (2000) SHRIMP zircon geochronology and geochemistry of the OrlicaŚnieżnik gneisses (Variscan belt of Central Europe) and their tectonic implications. Geodin Acta 13: 293-312

Urban M, Synek J (1995) Structure (Chapter VII.C.2). In: Dallmeyer RD, Franke W, Weber K (eds) Pre-Permian Geology of Central and Eastern Europe. Springer-Verlag, Berlin, pp 429-443

VANDERHAEGHE O (2001) Melt segregation, pervasive melt migration and magma mobility: the structural record from pores to orogens. Phys Chem Earth 26: 213-223

Verner K, Buriánek D, Vondrovic L, Pertoldová J, NAHOdilová R, HanžL P (2009) Tectonometamorphic features of geological units along the northern periphery of the Moldanubian Zone (Bohemian Massif). J Geosci 54: 87-100

Vernon RH, Johnson SE (2000) Transition from gneiss to migmatite and the relationship of leucosome to peraluminous granite in the Cooma Complex, SE Australia. In: Jessell MW, Urai JL (eds) Stress, Strain and Structure, A volume in honour of W D Means. J Virt Explorer 2, http://virtualexplorer.com.au/special/meansvolume/ contribs/vernon/ 
Villaseca C, Barbero L (1994) Chemical variability of $\mathrm{Al}-\mathrm{Ti}-\mathrm{Fe}-\mathrm{Mg}$ minerals in peraluminous granitoid rocks from central Spain. Eur J Mineral 6: 691-710

Winchester JA, Floyd PA, Crowley QG, Piasecki MAJ, Lee MK, Pharaoh TC, Williamson P, Banka D, Verniers J, Samuelsson J, Bayer U, Marotta AM, Lamarche J, Franke W, Dörr W, Valverde-Vaquero P, Giese U, Vecoli M, Thybo H, Laigle M, Scheck M, Maluski H, Marheine D, Noble SR, Parrish RR, Evans J, Timmerman H, Gerdes A, Guterch A, Grad M, Cwojdzinski S, Cymerman Z, Kozdrój W, Kryza R, Alexandrowski P., Mazur S, Štedrá V, Kotková J, Belka Z, Patočka F, KACHLíK V (2002) Palaeozoic amalgamation of Central
Europe; new results from recent geological and geophysical investigations. Tectonophysics 360: 5-21

ZavŘelová A, Melichar R, Verner K (2006) Structural evolution of metagranites from Svratka Crystalline Complex. In: KrmíčeK L., Přichystal A, Halavínová M (eds) Moravskoslezské Palezoikum 2006, Faculty of Science, Masaryk University Brno, pp 24 (in Czech)

Żelaźniewicz A, Nowak I, Larionov A, Presnyakov S (2006) Syntectonic Lower Ordovician migmatite and post-tectonic Upper Viséan syenite in the western limb of the Orlica-Śnieżnik Dome, West Sudetes: U-Pb SHRIMP data from zircons. Geol Sudetica 38: $63-80$ 